\title{
The oceanic fixed nitrogen and nitrous oxide budgets: Moving targets as we enter the anthropocene?*
}

\author{
L.A. CODISPOTI ${ }^{1}$, JAY A. BRANDES ${ }^{2}$, J.P. CHRISTENSEN ${ }^{3}$, A.H. DEVOL ${ }^{4}$, \\ S.W.A. NAQVI ${ }^{5}$, HANS W. PAERL ${ }^{6}$ and T. YOSHINARI ${ }^{7}$ \\ ${ }^{1}$ Univ. of Maryland Center for Environmental Science, Horn Point Lab., Cambridge, MD, 21613, U.S.A. \\ E-mail: codispot@hpl.umces.edu \\ ${ }^{2}$ University of Texas, Marine Science Institute, 750 Channelview Drive, Port Aransas, TX 78373, U.S.A. \\ ${ }^{3}$ Bigelow Laboratory for Ocean Sciences, 180 McKown Point, West Boothbay Harbor, ME 04575, U.S.A. \\ ${ }^{4}$ School of Oceanography, University of Washington, Seattle, WA 98195 , U.S.A. \\ ${ }^{5}$ National Institute of Oceanography, Dona Paula, Goa 403 004, India. \\ ${ }^{6}$ Institute of Marine Sciences, Univ. of North Carolina at Chapel Hill, Morehead City, NC, 28557, U.S.A. \\ ${ }^{7}$ Wadsworth Center, New York State Dept. of Health, Albany, NY 12201, U.S.A.
}

\begin{abstract}
SUMMARY: New data force us to raise previous estimates of oceanic denitrification. Our revised estimate of $\sim 450 \mathrm{Tg} \mathrm{N} \mathrm{yr}^{-1}$ $\left(\mathrm{Tg}=10^{12} \mathrm{~g}\right)$ produces an oceanic fixed $\mathrm{N}$ budget with a large deficit $\left(\sim 200 \mathrm{Tg} \mathrm{N} \mathrm{yr}^{-1}\right)$ that can be explained only by positing an ocean that has deviated far from a steady-state, the need for a major upwards revision of fixed $\mathrm{N}$ inputs, particularly nitrogen fixation, or both. Oceanic denitrification can be significantly altered by small re-distributions of carbon and dissolved oxygen. Since fixed $\mathrm{N}$ is a limiting nutrient, uncompensated changes in denitrification affect the ocean's ability to sequester atmospheric $\mathrm{CO}_{2}$ via the "biological pump". We have also had to modify our concepts of the oceanic $\mathrm{N}_{2} \mathrm{O}$ regime to take better account of the extremely high $\mathrm{N}_{2} \mathrm{O}$ saturations that can arise in productive, low oxygen waters. Recent results from the western Indian Shelf during a period when hypoxic, suboxic and anoxic waters were present produced a maximum surface $\mathrm{N}_{2} \mathrm{O}$ saturation of $>8000 \%$, a likely consequence of "stop and go" denitrification. The sensitivity of $\mathrm{N}_{2} \mathrm{O}$ production and consumption to small changes in the oceanic dissolved oxygen distribution and to the "spin-up" phase of denitrification suggests that the oceanic source term for $\mathrm{N}_{2} \mathrm{O}$ could change rapidly.
\end{abstract}

Key words: Arabian Sea, denitrification, global change, Indian Shelf, nitrogen budget, nitrogen cycle, nitrogen fixation, nitrous oxide, suboxia.

\section{INTRODUCTION}

The senior author (LAC) was educated in an era when his geological oceanography instructor felt obliged to teach both the pros and cons of continental drift and when El Niño was described as an essentially Peruvian-scale phenomenon. At that time (the 1960s), limitated observations and the principle of parsimony encouraged many to

\footnotetext{
*Received May 10, 2001. Accepted June 4, 2001.
}

assume an ocean that was in steady-state. Thus, when LAC's Ph.D. work (Codispoti, 1973; Codispoti and Richards, 1976) in combination with other studies (e.g. Cline, 1973; Devol, 1975) found enough denitrification to bring the oceanic fixed $\mathrm{N}$ budget, as it was then understood, into balance, the result was nothing more than expected. After all, many studies assumed a steady-state ocean, and even though we dutifully note our assumptions, their frequent use tends to color our view of how the real world works. A disturbing, present-day 
manifestation of this is the tendency to call mathematical model outputs, "data".

The development of our view of the oceanic N system, to some extent, parallels the journey of the climate change community. When LAC began his career, most students of climate felt that change was slow enough to permit oceanographers to assume a steadystate for the present-day ocean without being ridiculous. Now, we know from studies of ice-cores (e.g. Alley, 1995) that there are modes of significant global climate change that take place over a few years, and that ocean basins have significant $\sim$ annual to decadal variability, driven by El Niño/La Niña cycles, the North Atlantic Oscillation, the Arctic Oscillation (Thompson and Wallace, 1998), the Pacific Decadal Oscillation (Mantua et al.,1997; Stott et al., 2000), etc.

If this paper simply documented our "path to enlightenment" it would have little value. It is our opinion, however, that we cannot neglect the oceanic $\mathrm{N}$ cycle when we attempt to understand global change. In particular, we hope to show that the following hypotheses are worth testing:

1. Some of the terms in the oceanic $\mathrm{N}$ regime are much larger than thought just a few years ago, and this has implications for the ability of the oceanic $\mathrm{N}$ cycle to impact atmospheric $\mathrm{CO}_{2}$ and $\mathrm{N}_{2} \mathrm{O}$ on the sub-1000 year time scale.

2. Key portions of the oceanic $\mathrm{N}$ cycle respond dramatically to relatively small environmental changes, including anthropogenic changes.

3 . The oceanic fixed $\mathrm{N}$ budget is either considerably out of balance or present-day estimates of oceanic nitrogen fixation are much too low, or both.

4. Increasing inputs of nutrients into coastal waters from the atmosphere, groundwater, and runoff, encourage the development of suboxia and anoxia which lead to significant increases in oceanic denitrification and $\mathrm{N}_{2} \mathrm{O}$ emissions, and

5. Denitrification may make the ocean more $\mathrm{Fe}$ limited.

Magnuson (1990) describes how short-term environmental observations are embedded in the "invisible present" and cannot be properly interpreted without addressing longer-term change (in his case driven by El Niño/La Niña cycles). With respect to the oceanic fixed $\mathrm{N}$ budget and $\mathrm{N}_{2} \mathrm{O}$ turnover there is an additional and perhaps more significant issue: most studies have occurred during the last $\sim 50$ years, a time in which human impingements on the environment have become massive enough to cause some authors to coin a new term for the present era, the Anthropocene (e.g. Falkowski et al., 2000; Crutzen and Ramanathan, 2000). Thus, re-casting our results into periodic variations such as El Niño cycles and the North Atlantic Oscillation may be insufficient, as we move out of the relatively constrained climate realm that is described by ice-core data for the last 420,000 years (Falkowski et al., 2000). One thing is certain, we have already intervened massively in the global $\mathrm{N}_{2}$ cycle (Hellemans, 1998; Smil, 1997; Vitousek et al., 1997a and 1997b). For example, anthropogenic nitrogen fixation is now on the order of $140 \mathrm{Tg} \mathrm{N} \mathrm{yr}^{-1}$ vs a "natural" biotic terrestrial rate of 90-130 $\mathrm{Tg} \mathrm{N} \mathrm{yr}^{-1}$ (Galloway et al., 1995), and human activities have caused major increases in the fixed $\mathrm{N}$ content of runoff, groundwater and the atmosphere (Capone and Bautista, 1985; Howarth et al., 1996; Krest et al., 2000; Paerl, 1997; Paerl et al., 2000; Spalding and Exner, 1993).

\section{METHODS}

The methods used to collect most of our data are already described (Codispoti et al., 1991; Friederich et al., 1990; Morrison et al., 1998; Morrison et al., 1999). In addition, the data collected from the R/V T.G. Thompson, during US JGOFS Arabian Sea Cruises (Morrison et al., 1998) are available on the U.S. JGOFS web site (http://www1.whoi.edu).

We employ a new method, for estimating local $\mathrm{NO}_{3}^{-}$removals in the Arabian Sea. This method is based on ratios of inorganic $\mathrm{N}\left(\mathrm{NO}_{3}^{-}+\mathrm{NO}_{2}^{-}+\mathrm{NH}_{3}\right)$ to $\mathrm{PO}_{4}^{3-}$ (reactive phosphorus) in waters of the Arabian Sea. Conceptually, this method differs little from the $\mathrm{N}^{*}$ concept of Gruber and Sarmiento (1997). We reverse signs for convenience, and our lower N/P ratio and higher residual $\mathrm{P}$ value accounts for non-local denitrification signals advected into the Arabian Sea. Partly because of the necessity for highly precise $\mathrm{PO}_{4}^{3-}$ data, previous methods for estimating denitrification mediated nitrate removals in the Arabian Sea generally relied on nitrogen, temperature and oxygen (NTO) relationships. These methods give unrealistic values in the surface layers because of atmospheric exchange and phytoplankton processes, and they appear to underestimate the $\mathrm{NO}_{3}^{-}$ removals due to denitrification. Our new method is described more fully elsewhere (Uhlenhopp et al., in prep.). Briefly, it is based on Type II linear regressions of $\mathrm{PO}_{4}^{3-} v s$ inorganic $\mathrm{N}\left(\mathrm{NO}_{3}^{-}+\mathrm{NO}_{2}^{-}+\mathrm{NH}_{3}\right)$ on samples from the Thompson Arabian Sea cruises from depths of 100-1500 db, with oxygen concentrations $>65 \mu \mathrm{M}$. The resulting equation is: 


$$
\mathrm{N}_{\text {deficit }}=(14.89(\mathrm{P}-0.28)-\mathrm{N}) \mu \mathrm{M} \times 0.86,
$$

where, $\mathrm{N}_{\text {deficit }}$ is the estimate of the inorganic $\mathrm{N}$ $\left(\mathrm{NO}_{3}^{-}+\mathrm{NO}_{2}^{-}+\mathrm{NH}_{3}\right)$ removed from a water parcel by denitrification, $14.89=\Delta \mathrm{N} / \Delta \mathrm{P}$ (by atoms) as determined by the Type II regression, $\mathrm{P}=$ reactive phosphorus $\left(\mathrm{PO}_{4}{ }^{3-}\right), 0.28$ is the $\mathrm{PO}_{4}{ }^{3-}$ intercept at 0 inorganic $\mathrm{N}$, and 0.86 accounts for the reactive $\mathrm{P}$ released by the organic material re-mineralized by denitrification assuming that $\mathrm{N} / \mathrm{P}$ in local organic matter is 14.89 , and that consumption of $94.4 \mathrm{NO}_{3}^{-}$ by denitrification releases one $\mathrm{PO}_{4}{ }^{3-}$ (Richards, 1965; equation 3). We also present some excess $\mathrm{N}_{2}$ values arising from denitrification in the Arabian Sea (total excess $\mathrm{N}_{2}$ minus excess $\mathrm{N}_{2}$ produced elsewhere). These were calculated from N/Ar ratios determined by mass spectroscopy, and are more fully described in Uhlenhopp et al. (in prep.) and in Emerson et al. (1999).

Please note the following nomenclature: We use $\mathrm{PO}_{4}^{3-}$ to denote reactive phosphorus as determined by our autoanalyzer method (SCOR, 1996); for convenience, in writing stoichiometric equations, etc. we use $\mathrm{NH}_{3}$ to represent the sum of $\mathrm{NH}_{3}+\mathrm{NH}_{4}^{+}$, and we use $\mathrm{HS}^{-}$to represent the sum of $\mathrm{H}_{2} \mathrm{~S}, \mathrm{HS}^{-}$and $\mathrm{S}^{2-}$. Also note that all forms of nitrogen other than elemental $\mathrm{N}_{2}$ are referred to as fixed nitrogen (fixed N), and that we refer to the Eastern Tropical North Pacific and the Eastern Tropical South Pacific as the ETNP and ETSP, respectively.

\section{SCIENTIFIC BACKGROUND}

\section{Oceanic nitrogen cycle}

A simplified view of the oceanic $\mathrm{N}$ cycle is shown in Figure 1. This figure shows:

1. assimilatory uptake and reduction of nitrate during photosynthesis and heterotrophic bacterial growth (green arrows),

2. recycling of - III oxidation state $\mathrm{N}$ in the upper layers (purple arrows),

3. oxidation back to nitrate via nitrification (magenta arrows),

4. conversion of nitrate to $\mathrm{N}_{2}$ by denitrification (orange arrows), and

5. conversion of $\mathrm{N}_{2}$ to $-\mathrm{III}$ oxidation state $\mathrm{N}$ by nitrogen fixation (yellow arrow).

In the ocean and atmosphere, $\mathrm{N}_{2}$ at the 0 oxidation state is most abundant, followed by nitrate at the +5 state, and then various forms of $\mathrm{N}$ at $-\mathrm{III}\left(\mathrm{NH}_{3}\right.$,

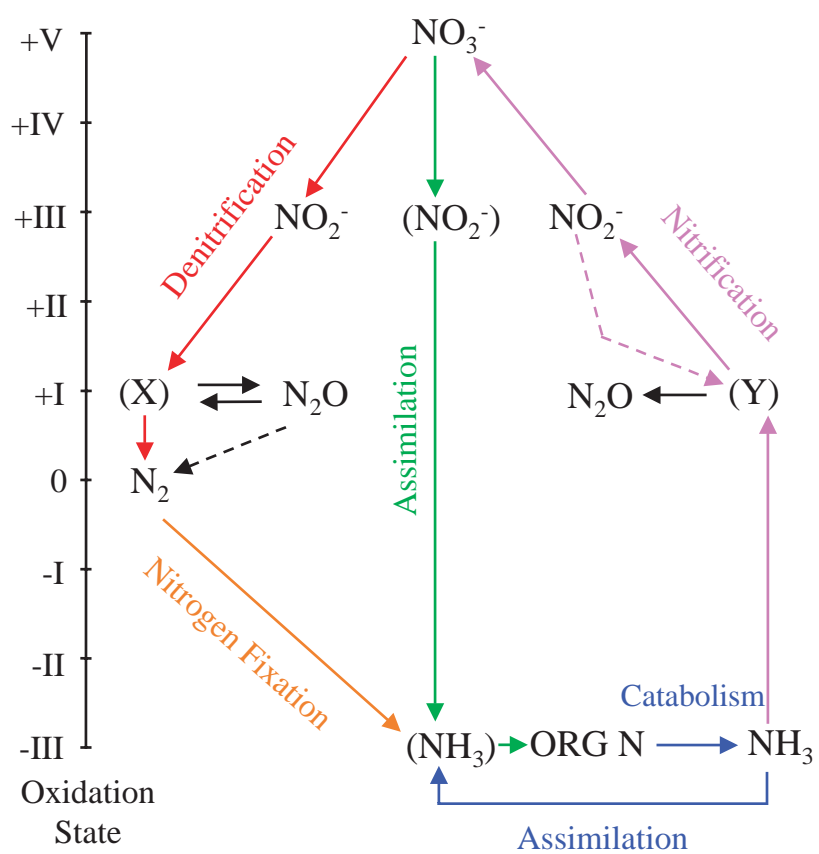

FIG. 1. - A simplified diagram of the oceanic nitrogen cycle based on an original figure presented by Liu (1979).

organic $\mathrm{N})$. Nitrite $\left(\mathrm{NO}_{2}^{-}\right)$builds up to concentrations that can rival $-\mathrm{III}$ and $+\mathrm{V} \mathrm{N}$ under suboxic conditions (Fig. 2). Although present in trace quantities, the $\mathrm{N}_{2} \mathrm{O}$ produced in the ocean has an important influence on atmospheric chemistry. Figure 1 leaves out some potentially important components about which we know little. These include, two labile components, hydroxylamine $\left(\mathrm{NH}_{2} \mathrm{OH}\right)$ and nitric oxide (NO) at the $-\mathrm{I}$ and + II oxidation states. These compounds have received some attention (e.g. Butler and Gordon, 1996; Ward and Zafiriou; 1988), but we lack sufficient data to draw useful conclusions about the relationship of these components to global change.

Figure 1 also describes processes that produce and consume $\mathrm{N}_{2} \mathrm{O}$, mainly:

1. the first step of nitrification (the -III to +III change) where $\mathrm{N}_{2} \mathrm{O}$ can be produced either by the break-down of an intermediate during $\mathrm{NH}_{3}$ oxidation to $\mathrm{NO}_{2}^{-}$or through reduction of $\mathrm{NO}_{2}^{-}$, a process that appears to be enhanced at low $\mathrm{O}_{2}$ and high $\mathrm{NO}_{2}^{-}$ concentrations (Capone, 1991; Poth and Focht, 1985; Ritchie and Nicholas, 1972; Ostrom et al., 2000), and

2. during denitrification where, depending on conditions, there may be net production or net consumption of $\mathrm{N}_{2} \mathrm{O}$.

There may be some uptake of $\mathrm{N}_{2} \mathrm{O}$ during nitrogen fixation (dashed black arrow in Fig. 1) when $\mathrm{N}_{2} \mathrm{O}$ 

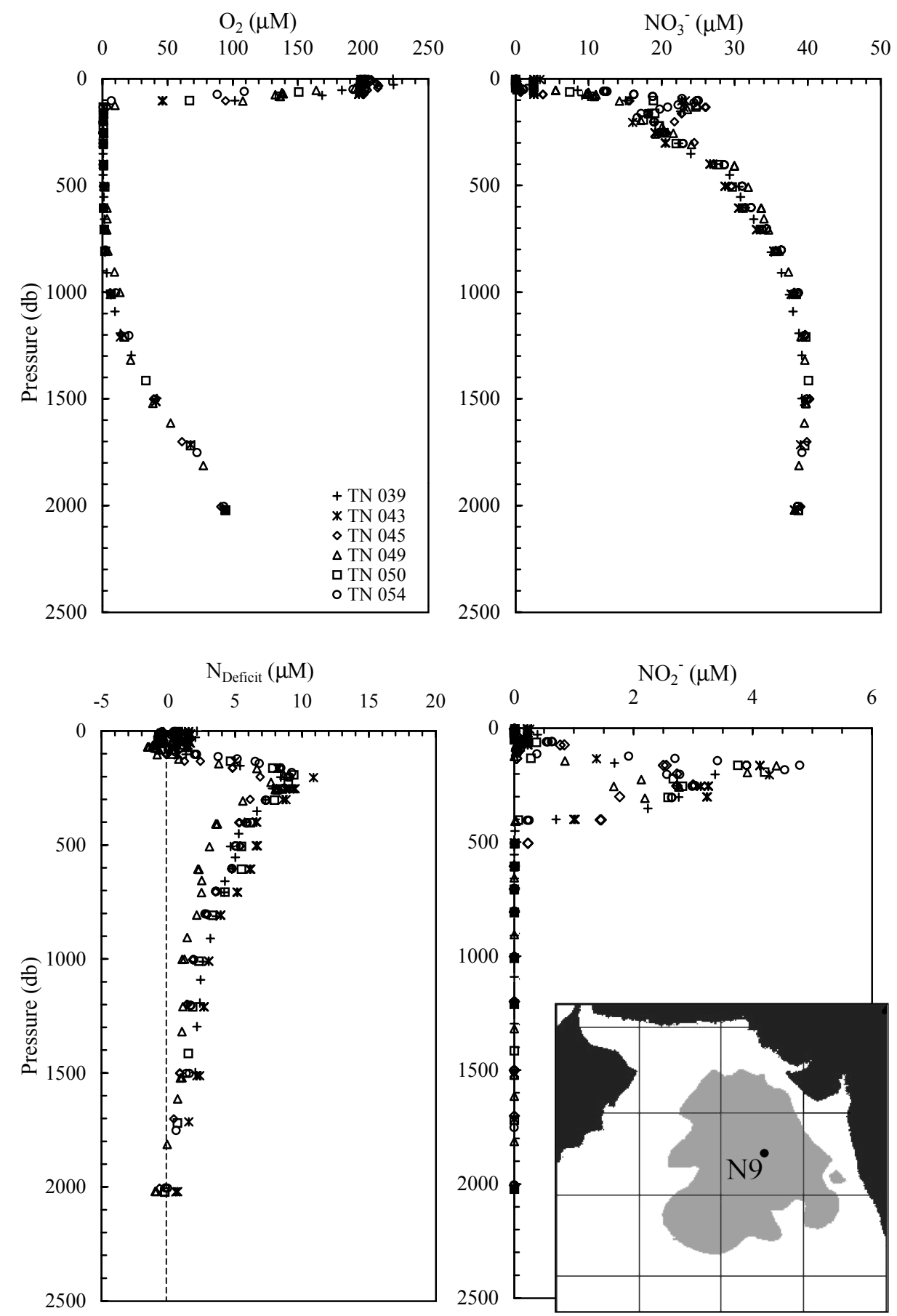

FIG. 2. - Data from station N9 located in the portion of the Arabian Sea that contains suboxic water at depths between $\sim 100-1000 \mathrm{db}$. Cruises, TN039, 43, 45, 49, 50 and 54 comprise the U.S. Joint Global Ocean Flux Process Study of the Arabian Sea and they cover a complete annual cycle beginning in September 1994 and ending in December 1995. A nitrate $\left(\mathrm{NO}_{3}^{-}\right)$minimum and nitrite $\left(\mathrm{NO}_{2}^{-}\right)$maximum within the suboxic zone $\left(\mathrm{O}_{2}<5 \mu \mathrm{M}\right)$ signal the presence of enhanced denitrification. The parameter, $\mathrm{N}_{\text {deficit }}$ estimates the conversion of $\mathrm{NO}_{3}^{-}$to $\mathrm{N}_{2}$ by denitrification. The shaded area indicates the extent of the regions where, on average, the maximum concentration of nitrite $\left(\mathrm{NO}^{-}{ }^{-}\right)$in the oxygen minimum zone (the secondary nitrite maximum) exceeds $1 \mu \mathrm{M}$ as described by Naqvi (1991). All concentrations are in $\mu \mathrm{M}$.

may be reduced to -III $\mathrm{N}$ along with $\mathrm{N}_{2}$ (Yamazaki et al., 1987). This effect is probably small because of the high $\mathrm{N}_{2} / \mathrm{N}_{2} \mathrm{O}$ ratio in seawater. Vertical profiles of $\mathrm{N}_{2} \mathrm{O}$ taken in $\mathrm{N}$ "starved" phytoplankton populations suggest no uptake in the absence of nitrogen fixation
(Mantoura et al., 1993). Additional sources of $\mathrm{N}_{2} \mathrm{O}$ have been suggested, including production during assimilatory and dissimilatory reduction of $\mathrm{NO}_{3}^{-}$to $\mathrm{NH}_{3}$ (e.g. Oudot et al., 1990; Tiedje, 1988), but based on existing knowledge, it seems reasonable to assume 
that these sources are not important to the topics that we will discuss. In addition to denitrification, loss to the atmosphere is the other major sink for oceanic $\mathrm{N}_{2} \mathrm{O}$. Studies of the isotopic composition of $\mathrm{N}_{2} \mathrm{O}$ (Dore et al., 1998; Kim and Craig, 1993; Yoshinari et al., 1997; Naqvi et al., 1998) present some conundrums suggesting that we still have more to learn about the pathways and intermediates involved in the production of oceanic $\mathrm{N}_{2} \mathrm{O}$ under varying environmental conditions.

While providing a useful overview, Figure 1 is greatly simplified. It omits, for example, direct reactions between reduced $\mathrm{S}$ and $\mathrm{NO}_{3}^{-}$that involve dissimilatory reduction of $\mathrm{NO}_{3}^{-}$to $\mathrm{NH}_{3}$ (Einsle et al., 1999). Lately, there has been heightened interest in bacteria (Thioploca, Beggiatoa, Thiomargarita namibiensis) that can store and transport $\mathrm{NO}_{3}^{-}$from overlying waters to sulfide-bearing sediments (e.g. Fossing et al., 1995; Schulz et al., 1999). These bacteria contain giant vacuoles that can store $\mathrm{NO}_{3}{ }^{-}$at concentrations of several hundred mM (Jørgensen and Gallardo, 1999; Fossing et al., 1995; Otte et al., 1999), with a high of $\sim 800 \mathrm{mM}$ reported for Thiomargarita namibiensis (Schulz et al., 1999). The vacuoles have been described as "anaerobic lungs" (Jørgensen and Gallardo, 1999), and they enable the bacteria to support chemotrophic growth (Otte et al., 1999) through dissimilatory nitrate reduction or denitrification linked to the oxidation of hydrogen sulfide (HS). Most of the $\mathrm{NO}_{3}^{-}$appears to be converted to $\mathrm{NH}_{3}$ during this reduction (Jørgensen and Gallardo, 1999; Otte et al., 1999), but the possibility of some $\mathrm{N}_{2}$ production has not been totally excluded. In addition, there are thiosulfate $\left(\mathrm{S}_{2} \mathrm{O}_{3}{ }^{2-}\right)$ oxidizing bacteria that are known to produce $\mathrm{N}_{2}$ (e.g. Thiobacillus denitrificans; Stouthamer, 1988).

The following important interactions are also not described by Figure 1:

Dependence on dissolved $\mathrm{O}_{2}$ concentrations: Nitrogen fixation, denitrification, and production of $\mathrm{N}_{2} \mathrm{O}$ during nitrification either require or are enhanced by low oxygen concentrations. Specifically, the enzyme system required for nitrogen fixation (nitrogenase) is poisoned by $\mathrm{O}_{2}$ (e.g. Falkowski, 1997; Paerl and Zehr, 2000), denitrification is inhibited at oxygen concentrations $>5 \mu \mathrm{M}$ (see below), and net production of $\mathrm{N}_{2} \mathrm{O}$ during nitrification increases markedly at low oxygen concentrations (Codispoti et al., 1992; Goreau et al., 1980; Suntharalingam et al., 2000).

Interactions with $\mathrm{Fe}$ : By removing fixed $\mathrm{N}$ from the ocean, denitrification creates a need for addition- al nitrogen fixation in order to maintain oceanic primary production. Since nitrogen fixation has an $\mathrm{Fe}$ requirement $\sim 60$ times greater than uptake of $\mathrm{NO}_{3}^{-}$ by phytoplankton (e.g. Falkowski, 1997; Raven, 1988), denitrification may make the ocean more Fe limited. While it is true that oxygen minimum zone (OMZ) waters in the Arabian Sea contain Fe concentrations a few $\mathrm{nM}$ higher than surrounding waters (Saagar et al., 1989; Witter et al., 2000), the stoichiometries involved (Bruland et al., 1991) suggest that $\sim 20 \mathrm{nM}$ of Fe are required to support enough nitrogen fixation to account for each $\mu \mathrm{M}$ of fixed $\mathrm{N}$ removed by denitrification, and fixed $\mathrm{N}$ removals in the suboxic portion of the Arabian Sea water column can exceed $20 \mu \mathrm{M}$, thereby imposing an Fe requirement of several hundred nM. Indeed, it is not clear whether elevated Fe concentrations seen in suboxic zones are related to the suboxia/denitrification per se, or to other factors such as advection of Fe from anoxic zones. It is clear that $\mathrm{Fe}$ concentrations of $>100$ $\mathrm{nM}$ tend to be associated with anoxia not suboxia, and it is possible that $\mathrm{NO}_{3}^{-}$can oxidize Fe II to less soluble Fe III (Murray et al., 1995).

Differential $C / N$ ratios: During phytoplankton growth the atomic ratio of N/C uptake is $\sim 6.6$ (Redfield et al., 1963), but during denitrification (see equations 2-6, below), the ratio (by atoms) of $\mathrm{N}_{2}$ production to $\mathrm{C}$ oxidation is <1 (Codispoti et al., 1989; equations 3-5). Therefore, once enough organic material has been oxidized to produce suboxic conditions, it would take only an additional < $1 / 6$ of the $C$ fixed by phytoplankton growth to fuel sufficient denitrification to consume all of the fixed $N$ that supported that growth.

Control of atmospheric $\mathrm{O}_{2}$ : At chemical equilibrium, virtually all of the oxygen in the atmosphere and ocean would be combined with $\mathrm{N}$ in the $+\mathrm{V}$ oxidation state (Lewis and Randall, 1923). Hutchinson (1975) suggests that were it not for the conversion of fixed $\mathrm{N}$ to $\mathrm{N}_{2}$ by denitrification, the sea would be an anoxic weak solution of nitric acid with a $\mathrm{pH}$ of $\sim 2$. The basic idea is that the fixed $\mathrm{N}$ produced by nitrogen fixation, lightning discharges and combustion would eventually get oxidized to the +5 state $\left(\mathrm{NO}_{3}^{-}\right)$ and deplete $\mathrm{O}_{2}$. The turnover times for $\mathrm{O}_{2}$ and $\mathrm{N}_{2}$ in the atmosphere under present-day conditions are, however, in the millions of years. Thus, this problem falls outside the scope of this paper.

Effect on the oceanic biological C pump: Fixed $\mathrm{N}$ and $\mathrm{Fe}$ limitation constrain primary production in most of the ocean (e.g. Falkowski, 1997) and thus limit the oceanic biological pump's ability to 
sequester atmospheric $\mathrm{CO}_{2}$. During periods when denitrification is removing fixed $\mathrm{N}$ from the ocean, the pump can be reversed and ocean biology can add rather than subtract $\mathrm{CO}_{2}$ to the atmosphere (e.g. Codispoti et al., 1989). Conversely, the pump would be enhanced when nitrogen fixation exceeds denitrification (Broecker and Henderson, 1998).

Constraints on oceanic nitrogen fixation: We have already mentioned the constraints that the presence of dissolved oxygen and Fe limitation can impose on nitrogen fixation. Paerl and Zehr (2000) list several others including turbulence which can interfere with the mechanisms for protecting against oxygen, a high-energy requirement, and, in some cases, limitation by $\mathrm{PO}_{4}^{3-}$.

\section{Oceanic fixed $\mathbf{N}$ budget}

Unlike the oceanic budgets for $\mathrm{Fe}, \mathrm{P}$, and $\mathrm{Si}$ that are dominated by riverine or atmospheric inputs and sedimentary sinks, the oceanic fixed $\mathrm{N}$ budget is heavily influenced by biological processes. Although there is a wide variation in estimates for each term (Gruber and Sarmiento, 1997; Table 1), it is clear that denitrification is the dominant sink. Nitrogen fixation is the most important source, at least for the pre-industrial period (e.g. Gruber and Sarmiento, 1997), but recent estimates (Table 1) suggest that it does not dominate the source terms,

TABLE 1. - Gruber and Sarmiento's fixed N budget for the presentday ocean and the changes suggested in this paper.

$\begin{array}{rr}\text { Gruber and Sarmiento } & \text { This paper's } \\ \text { Process } & \text { updated } \\ \text { values }\end{array}$

\begin{tabular}{|c|c|c|}
\hline \multicolumn{3}{|l|}{ Sources } \\
\hline \multicolumn{3}{|l|}{ Pelagic $\mathrm{N}_{2}$ fixation } \\
\hline Benthic $N_{2}^{2}$ fixation & $15 \pm 10$ & \\
\hline River input (DN) & $34 \pm 10$ & \\
\hline River input (PON) & $42 \pm 10$ & \\
\hline Atmospheric deposition (Net) & $30 \pm 5$ & \\
\hline Atmospheric deposition (DON) & & $56^{\mathrm{a}}$ \\
\hline Total Sources & $231 \pm 44$ & 287 \\
\hline Sinks & & \\
\hline Organic N export & & $1^{\mathrm{b}}$ \\
\hline Benthic denitrification & $95 \pm 20$ & 300 \\
\hline Water column denitrification & $80 \pm 20$ & 150 \\
\hline Sedimentation & $25 \pm 10$ & \\
\hline $\mathrm{N}_{2} \mathrm{O}$ loss & $4 \pm 2$ & 6 \\
\hline Total Sinks & $204 \pm 30$ & 482 \\
\hline
\end{tabular}

a Average atmospheric organic N (mostly anthropogenic) deposition value suggested by Cornell et al. (1995).

b Accounts for losses due to fishing and guano deposition (Söderlund and Svensson, 1976; Codispoti and Christensen, 1985) in the present-day ocean, to the same degree that denitrification dominates the sinks. For example, Cornell et al. (1995) suggest that, at present, there may be a large unaccounted for source of anthropogenic atmospheric dissolved organic $\mathrm{N}$ (DON) to the ocean ranging from $28-84 \mathrm{Tg} \mathrm{N} \mathrm{yr}^{-1}$. More generally, we know that anthropogenic activities have doubled the riverine and atmospheric inputs of fixed $\mathrm{N}$, and that groundwater inputs have increased and may be underestimated (Capone and Bautista, 1985; Galloway et al., 1995; Duce et al., 1991; Howarth et al., 1996; Moore, 1996; Paerl, 1997). On the other hand, the riverine estimates in Table 1 may be too high because some of the studies on which they are based may not account for removal in estuaries and our focus is on the continental shelf and open ocean. The work of Nixon et al. (1996) suggests that a considerable fraction of the riverine input is removed by sedimentation or denitrification in estuaries. Moreover, some Type II (negative) estuaries (Smith et al., 1989) represent sinks for oceanic fixed $N$, because inflowing ocean waters have some of their fixed $\mathrm{N}$ removed by sedimentation and denitrification. Since we have a very poor idea of the ground-water inputs of fixed $\mathrm{N}$ to the open ocean, we will retain the total value of $\sim 160 \mathrm{Tg} \mathrm{N} \mathrm{yr}^{-1}$ for riverine, atmospheric and groundwater fixed $\mathrm{N}$ inputs to the present-day ocean. Since this value exceeds most existing estimates for oceanic nitrogen fixation (Table 1), it might be fair to assert that only the sink-term for oceanic fixed $\mathrm{N}$ in today's ocean is dominated by internal biological processes. Major points of this paper are, however, that:

1. Recent advances in our understanding require a significant upwards revision of the oceanic denitrification rate, which, in turn, requires,

2. a major increase in estimates of oceanic nitrogen fixation to achieve a balance, or

3. a drastic change in our concepts of how to interpret existing data.

Thus, it is entirely possible that oceanic nitrogen fixation is the major source of marine fixed $\mathrm{N}$.

Until recently, a common assumption amongst geochemists was that denitrification/nitrogen fixation represented a well-coupled negative feed-back mechanism. Although there were exceptions (McElroy, 1983), most geochemists blithely dismissed the importance of fixed $\mathrm{N}$ as a limiting nutrient with respect to problems such as the ability of the oceanic biological pump to sequester atmospheric $\mathrm{CO}_{2}$ (e.g. Bolin et al., 1983). As noted earlier, assuming that a budget is in a steady-state has its attractions. 
Moreover, models of global change could be simplified, if the (on average) slight excess of $\mathrm{P} v s$ fixed $\mathrm{N}$ availability to phytoplankton existed only because you need a slight excess of $\mathrm{P}$ over fixed $\mathrm{N}$ to "drive" nitrogen fixation. In a weakened state, this view continues to the present-day (Tyrell, 1999). There is increasing recognition, however, that imbalances in the oceanic fixed $\mathrm{N}$ budget can be large enough and last long enough to have a significant influence on atmospheric $\mathrm{CO}_{2}$ (e.g. Codispoti, 1989; Falkowski, 1997; Lenton and Watson, 2000). This is partially because the sites of enhanced nitrogen fixation and denitrification are often separated. Denitrification is enhanced in suboxic subsurface waters and sediments, whereas it follows from the constraints on nitrogen fixation that the main openocean sites of nitrogen fixation are warm, stratified surface waters (e.g. Capone et al., 1997; Carpenter and Romans, 1991) with an abundant Fe supply (Falkowski, 1997) supplemented by fixation in some shallow benthic communities where nitrogen fixation and denitrification may co-occur (Paerl and Zehr, 2000). Thus, a fixed $\mathrm{N}$ deficiency relative to $\mathrm{P}$ is not a sufficient condition for nitrogen fixation (Codispoti, 1989).

Ultimately, imbalances in the fixed $\mathrm{N}$ source and sink terms are coupled through ocean circulation (Broecker and Peng, 1982; Codispoti, 1989). For example, if denitrification exceeds nitrogen fixation for a period, oceanic primary production should be reduced due to the draw down of fixed N. Eventually, this should reduce primary production leading to a decrease in the downward flux of organic matter, a decrease in subsurface respiration, and finally a reduction in the volume of suboxic environments where denitrification is enhanced. Of course, exactly what happens would depend on the details of circulation, flux and productivity patterns, but the point is that fixed $\mathrm{N}$ in the ocean cannot be drawn down continuously before the overall decrease in fixed $\mathrm{N}$ would depress denitrification rates. The time scale for this circulation-based feedback is probably in the range of several hundred to $\sim 1000$ years, again depending on the details. So the question becomes, how out of balance could the system become? Gruber and Sarmiento (1997) suggest that imbalances of $70 \mathrm{Tg} \mathrm{N} \mathrm{yr}{ }^{-1}$ could not persist for more than $\sim 300$ years without causing changes that would exceed the range of atmospheric $\mathrm{CO}_{2}$ concentrations over the last millenium $(280 \pm 10 \mathrm{ppm})$ suggesting that oceanic nitrogen budget imbalances have not exceeded this during this relatively quiet climatic period. Falkowski (1997) points out that only small imbalances, of the order of $3 \mathrm{Tg} \mathrm{N} \mathrm{yr}-1$, would be sufficient to account for a major fraction of the variability in atmospheric $\mathrm{CO}_{2}$ over the $\sim 10,000$ year period during which atmospheric $\mathrm{CO}_{2}$ concentrations fell from $\sim 290$ to $\sim 190 \mathrm{ppm}$ as we entered the last glaciation. In this work, we are taking a more prospective view and ask:

Are we in a transition state as we enter the Anthropocene in which the deficit in the oceanic fixed $N$ budget exceeds $\sim 200 \mathrm{Tg} \mathrm{N} \mathrm{yr}^{-1}$, or are we significantly underestimating oceanic nitrogen fixation, or both?

\section{The denitrification sink}

The main identified sites of denitrification in the ocean are shelf and hemipelagic sediments (Christensen et al., 1987; Devol, 1991) and suboxic $\left(\mathrm{O}_{2}<\right.$ $\sim 5 \mu \mathrm{M})$ portions of the oxygen minimum zone (OMZ). The traditional view has been that shallow sediments dominate over abyssal sediments (Christensen et al., 1987; Devol et al., 1997) despite their relatively small area because of their high organic material supply. A model study of benthic denitrification by Middleburg et al. (1996), however, suggests that denitrification in slope and abyssal sediments exceeds benthic denitrification in shelf sediments. These authors note that estimates of denitrification in deep sediments are few, and are often based on flawed methods that, for example, only considered $\mathrm{NO}_{3}^{-}$fluxes into the sediments, neglecting the frequently more important influence of coupled nitrification-denitrification (e.g. Codispoti and Christensen, 1985; Seitzinger et al., 1993). Middleburg et al. suggest that at depths between $\sim 500$ $3000 \mathrm{~m}$ the relative contribution of denitrification in sedimentary organic matter mineralization exceeds $10 \%$ with a maximum near $2000 \mathrm{~m}$.

The major identified sites of water column denitrification occur in the ETNP (e.g. Cline and Richards, 1972; Codispoti and Richards, 1976), the ETSP (e.g. Codispoti and Packard, 1980), and the Arabian Sea (Bange et al., 2000; Mantoura et al., 1993; Naqvi, 1987; Naqvi and Sen-Gupta, 1985). Smaller, and more transient sites occur near the boundaries of the three major identified sites (e.g. Codispoti and Packard, 1980; Codispoti et al., 1986). There also appears to be a significant body of suboxic water off SW Africa (Calvert and Price, 1971), but we can find no estimates of denitrification rates for this region. 


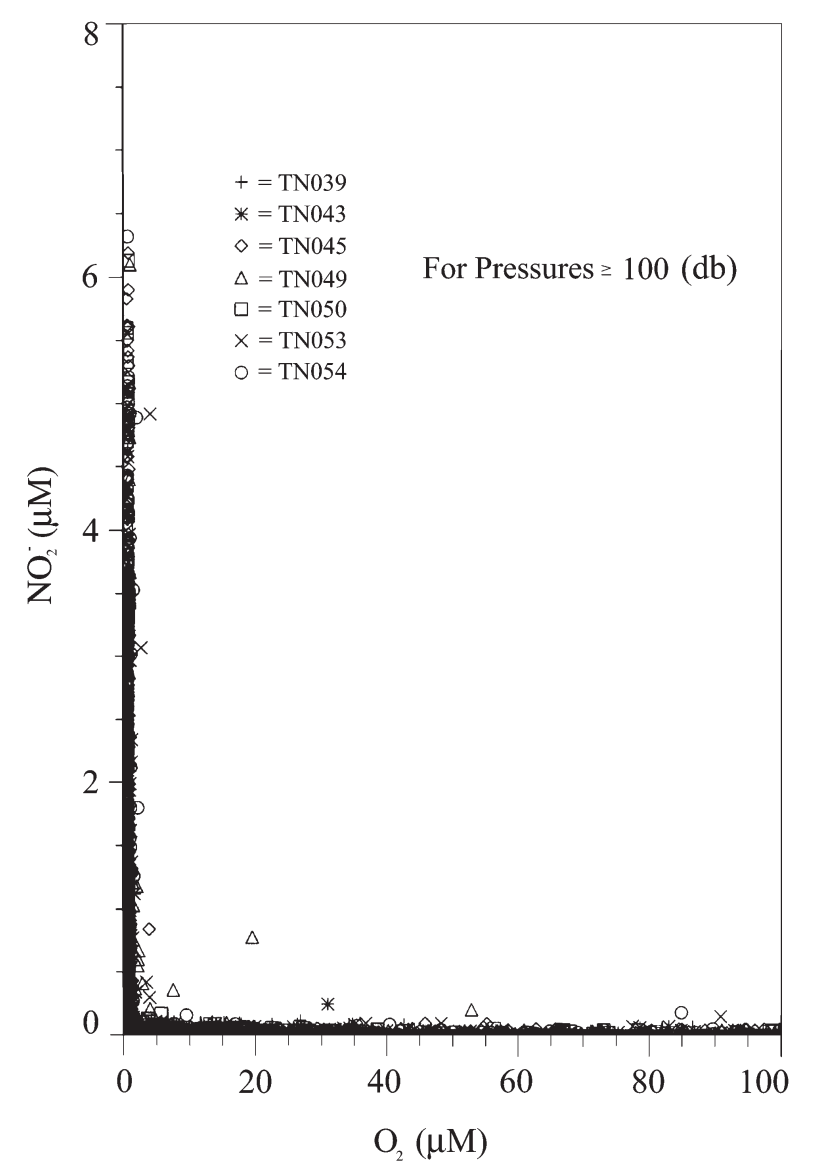

FIG. 3. - Nitrite $\left(\mathrm{NO}_{2}{ }^{-}\right)$concentrations $(\mu \mathrm{M})$ versus oxygen concentrations $(\mu \mathrm{M})$ from depths $\geq 100 \mathrm{db}$, observed during a seasonal cycle in the Arabian Sea (see Fig. 2). The bulk of the elevated nitrite $\left(\mathrm{NO}_{2}^{-}\right)$concentrations occur at oxygen concentrations of $<2.5 \mu \mathrm{M}$ (from Morrison et al., 1998).

Anthropogenic impacts have led to increasing coastal hypoxia/suboxia/anoxia leading to water column denitrification over the Indian Shelf (Naqvi et al., 2000a), in the Baltic Sea (Shaffer and Rönner, 1984), and probably off the mouth of the Mississippi River (Rabalais et al., 2000). We also know that denitrification occurs in suboxic layers sandwiched between the oxic and anoxic layers in the Black Sea (e.g. Codispoti et al., 1991, Fig. 4) and the Cariaco Trench (Scranton et al, 1987; Richards, 1975; Richards and Benson, 1960), and in California Borderland basins (Stott et al., 2000; Liu, 1979; Codispoti, 1973). Given the expansion of low oxygen conditions in coastal waters (Malakoff, 1998) and the paucity of data, there may be several additional sites of water column suboxia and enhanced denitrification. For example, dissolved oxygen data from the Scorpio Expedition (Reid, 1973) suggest the presence of suboxic water in the S. Pacific, in regions that have never been closely examined.

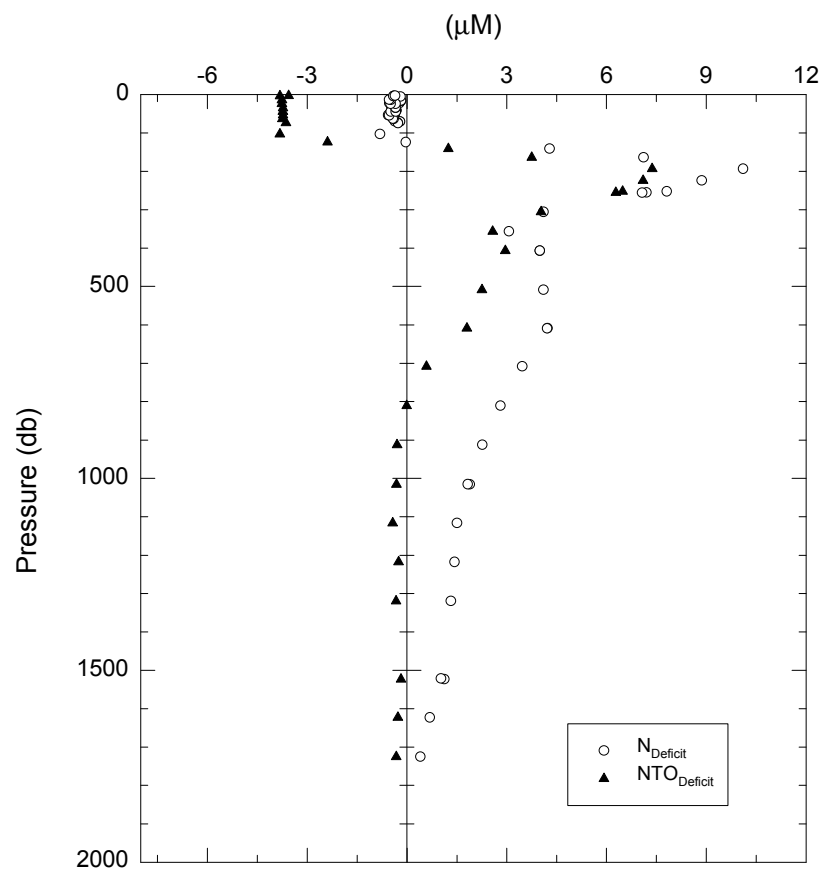

FIG. 4. - A comparison of nitrate deficits in the Arabian Sea computed by a frequently used method based on relationships between inorganic $\mathrm{N}$, dissolved oxygen and temperature $\left(\mathrm{NTO}_{\text {defici }}\right)$ and described in Naqvi (1994), with the phosphate based method $\left(\mathrm{N}_{\text {deficit }}\right)$ described herein. These results are from U.S. JGOFS Arabian Sea cruise TN049, station M1 $\left(14.9^{\circ} \mathrm{N}, 66.9^{\circ} \mathrm{E}\right)$ Concentrations are in $\mu \mathrm{M}$ of $\mathrm{NO}_{3}^{-}$removed.

Data from the Arabian Sea suboxic zone (Figs. 27) display the conditions under which water column denitrification is favored. The co-occurrence of low $\mathrm{O}_{2}$ and high $\mathrm{NO}_{2}^{-}$in the suboxic zone signals an environment with high denitrification rates. These nitrite concentrations tend to build-up only when oxygen concentrations are $<\sim 2.5 \mu \mathrm{M}$ (Fig. 3), so our suggestion that suboxia begins at $\mathrm{O}_{2}$ concentrations less than $5 \mu \mathrm{M}$ may be generous. Although there appears to be a correlation between denitrification rates and $\mathrm{NO}_{2}^{-}$concentrations (Codispoti and Packard, 1980), this does not mean that denitrification does not occur in suboxic waters with low $\mathrm{NO}_{2}^{-}$. For example, in the northern Arabian Sea and in the bottom portion of the suboxic zone, we sometimes see appreciable nitrate deficits (Figs. 5 and 6) even though $\mathrm{NO}_{2}^{-}$is low, suggesting that denitrification may continue to occur, albeit at presumably lower rates. In the past, we (LAC and SWAN) have only included suboxic waters with appreciable $\mathrm{NO}_{2}^{-}$ ( $>0.2$ to $>0.5 \mu \mathrm{M}$ depending on the region) when using respiration estimates based on the activity of the electron transport system (ETS) to calculate denitrification rates. This helped to account for the possibility of $\mathrm{NO}_{2}^{-}$diffusing out of the denitrification 

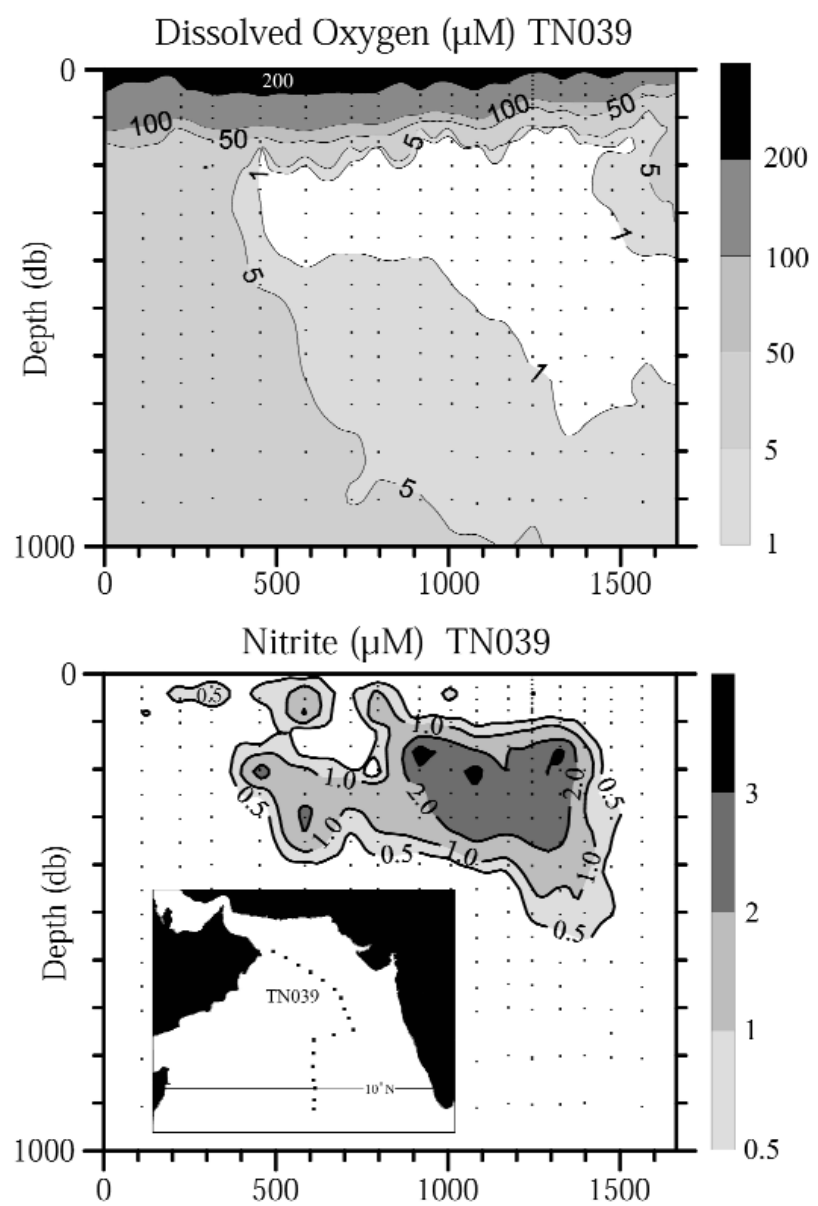

FIG. 5. - Dissolved oxygen and nitrite sections taken in the Arabian Sea during the first U.S. JGOFS Arabian Sea cruise (TN039, Sept.Oct. 1994). Oxygen concentrations were determined by automated Winkler titration and compared with the low-concentration colorimetric method of Broenkow and Cline (1969). Concentrations are in $\mu \mathrm{M}$.

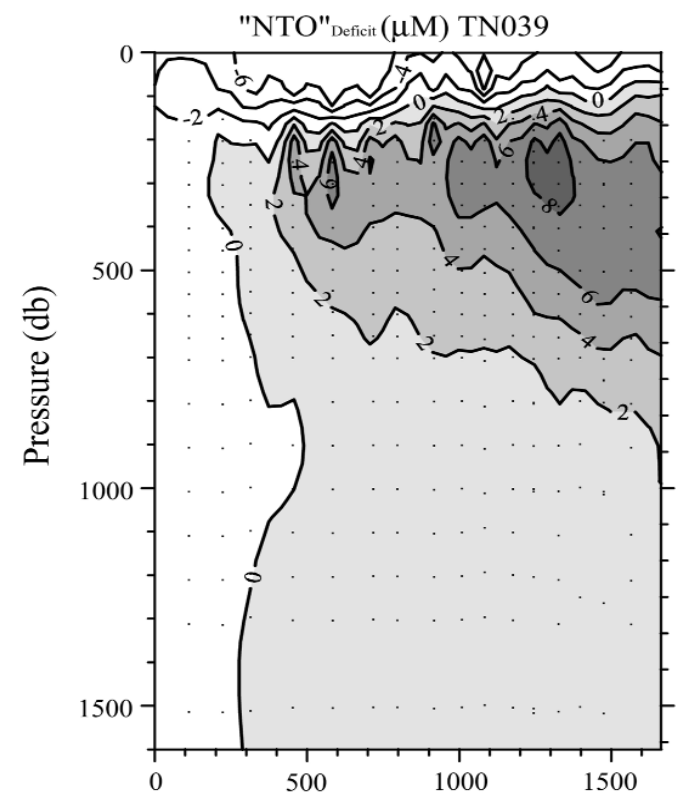

zone and escaping further reduction (Anderson et al., 1982; Codispoti and Christensen, 1985), but may be too restrictive for the lower portion of the suboxic zone where suboxia and high $\mathrm{N}_{\text {deficits }}$ extend to considerable depths even though $\mathrm{NO}_{2}^{-}$is low (Figs. 5 and 6). Thus, the deep $\mathrm{N}_{\text {deficits }}$ may arise from a combination of local denitrification as well as from the transport of deficits produced elsewhere.

Note that the known suboxic zones in today's ocean comprise only $\sim 0.1 \%$ of the total oceanic volume. We know (Table 1) that globally significant denitrification occurs within this volume. It follows, therefore, that small changes in dissolved oxygen distributions and carbon fluxes can have globally significant effects on water column denitrification. Calculations suggest that an additional $5 \%$ of primary production added to the suboxic waters in the ETSP could double the denitrification rate, and this calculation was based on old primary productivity data that might be too low (Codispoti, 1989). In addition, Codispoti and Packard (1980) and Codispoti et al. (1986) have described what appear to be globally significant accelerations in denitrification in the ETSP. One of these followed the collapse of the Peruvian anchoveta fishery, and the other was associated with the 1985 La Niña (Codispoti et al., 1986; Codispoti et al., 1988). The sedimentary record provides evidence for globally significant changes in oceanic denitrification over much longer time intervals (Altabet et al., 1995; Ganeshram et al., 1995). We conclude that not only is the oceanic

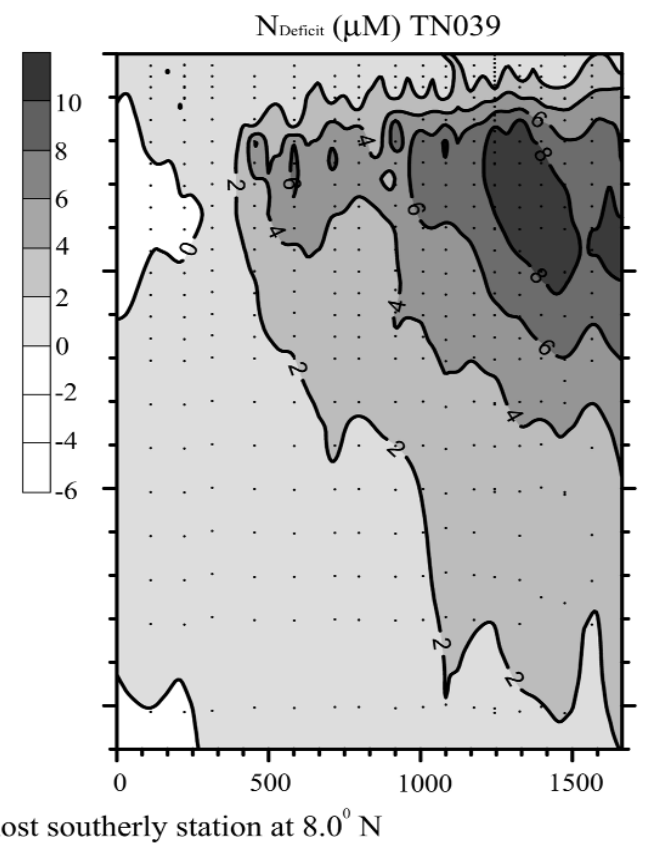

FIG. 6. - Distributions of $\mathrm{NTO}_{\text {deficit }}$ and $\mathrm{N}_{\text {deficit }}$ in the same section shown in Figure 5. Concentrations are in $\mu \mathrm{M}$. 
denitrification regime sensitive to change, but that it does undergo significant change over a wide range of time scales.

Based on the traditional concepts of denitrification and the concept of "Redfield ratios", Richards (1965) suggested the following two possible stoichiometric equations for oceanic denitrification:

$$
\begin{gathered}
\left(\mathrm{CH}_{2} \mathrm{O}\right)_{100}\left(\mathrm{NH}_{3}\right)_{16} \mathrm{H}_{3} \mathrm{PO}_{4}+84.8 \mathrm{HNO}_{3}= \\
=106 \mathrm{CO}_{2}+42.4 \mathrm{~N}_{2}+148.4 \mathrm{H}_{2} \mathrm{O}+16 \mathrm{NH}_{3}+\mathrm{H}_{3} \mathrm{PO}_{4}
\end{gathered}
$$

and

$$
\left(\mathrm{CH}_{2} \mathrm{O}\right)_{106}\left(\mathrm{NH}_{3}\right)_{16} \mathrm{H}_{3} \mathrm{PO}_{4}+94.4 \mathrm{HNO}_{3}=
$$$$
=106 \mathrm{CO}_{2}+55.2 \mathrm{~N}_{2}+177.2 \mathrm{H}_{2} \mathrm{O}+\mathrm{H}_{3} \mathrm{PO}_{4} \text {. }
$$

The major difference between the two equations involves the fate of organic N. In Equation (3), total $\mathrm{N}_{2}$ production, exceeds $\mathrm{NO}_{3}{ }^{-}$consumption by $17 \%$. Gruber and Sarmiento (1997) present an updated version of Equation (3) based on the elementary composition of surface ocean plankton (upper $400 \mathrm{~m}$ ) suggested by Anderson (1995) in which total $\mathrm{N}_{2}$ production exceeds $\mathrm{NO}_{3}{ }^{-}$consumption by $15 \%$. As we shall show, even Equation (3) appears to greatly underestimate the ratio of $\mathrm{N}_{2}$ produced to $\mathrm{NO}_{3}^{-}$consumed during denitrification, as do updated versions of Richards' equations presented by Codispoti and Christensen (1985). This is important when estimating denitrification rates based on parameters such as $\mathrm{N}_{\text {deficit }}$ In the past, estimates of denitrification have assumed that none or only a fraction of the organic $\mathrm{N}$ was converted to $\mathrm{N}_{2}$ (e.g. Codispoti and Richards, 1976). Direct estimates of the excess $N_{2}$ present in suboxic waters of the Arabian Sea (Fig. 7), however, suggest that the actual production of $\mathrm{N}_{2}$ is much higher as do some preliminary excess $\mathrm{N}_{2}$ estimates from the eastern tropical North Pacific (Brandes, 1996). Although $\mathrm{N}_{\text {deficit }}$ gives integrated water column estimates of the nitrate removed by denitrification that are about twice as high as older methods (Fig. 6), integrated water column values of $\mathrm{N}_{\text {deficit }}$ are only about half as large as the estimates of excess $\mathrm{N}_{2}$. Therefore, integrated excess $\mathrm{N}_{2}$ may exceed the older Arabian Sea nitrate deficits by a factor of $\sim 4$.

Equation (3) and its more recent analogues can explain about $15 \%$ of the difference between $\mathrm{N}_{\text {deficit }}$ and excess $\mathrm{N}_{2}$, but where does the rest of the $\mathrm{N}_{2}$ come from? One explanation is that denitrification does not follow the traditional stoichiometries that vary only a little between authors (Richards, 1965; Codispoti and Christensen, 1985; Gruber and Sarmiento, 1997). In support of this notion, Van

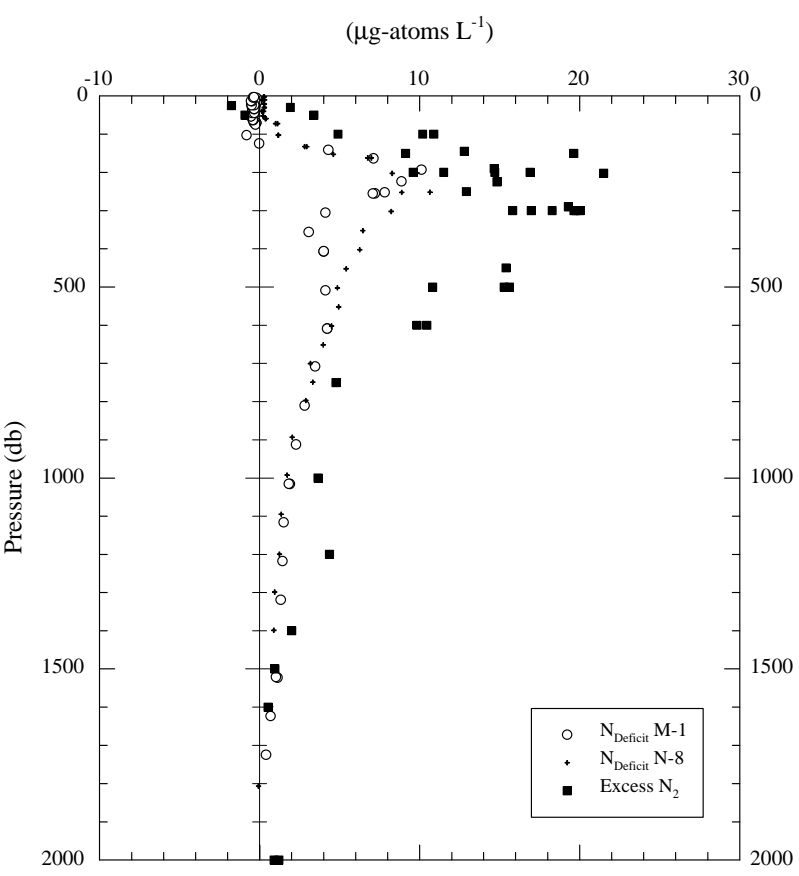

FIG. 7. - A comparison of nitrate deficits $\left(\mathrm{N}_{\text {defici }}\right)$ at stations $\mathrm{N} 8$ (TN043, $18.25^{\circ} \mathrm{N}, 67.6^{\circ} \mathrm{E}$ ) and M1, TN049 (see Fig. 4) with our ensemble of excess $\mathrm{N}_{2}$ concentrations in the Arabian Sea. Concentrations are in $\mu$ g-atoms of $\mathrm{N} \mathrm{L}^{-1}$ (for $\mathrm{N}_{\text {deficit }}, \mu \mathrm{M}=\mu$ g-atoms of $\mathrm{N} \mathrm{L}^{-1}$ ).

Mooy et al's. (in press) results suggest that denitrifying bacteria in the suboxic portion of the ETNP preferentially attack amino acids with a $\mathrm{C} / \mathrm{N}$ ratio of about 4 (by atoms) $v s$ the ratio of $\sim 6.6$ for "Redfieldian" organic matter. Starting with Gruber and Sarmiento's (1997) stoichiometric equation for denitrification:

$$
\begin{gathered}
\mathrm{C}_{106} \mathrm{H}_{175} \mathrm{O}_{42} \mathrm{~N}_{16} \mathrm{P}+104 \mathrm{NO}_{3}^{-}= \\
=4 \mathrm{CO}_{2}+102 \mathrm{HCO}_{3}^{-}+60 \mathrm{~N}_{2}+36 \mathrm{H}_{2} \mathrm{O}^{-}+\mathrm{HPO}_{4}{ }^{2-}
\end{gathered}
$$

Van Mooy et al. assumed that the organic carbon oxidized by denitrifiers consists of an ideal protein (Anderson, 1995), and they produced the following equation for denitrification:

$$
\begin{gathered}
\mathrm{C}_{61} \mathrm{H}_{97} \mathrm{O}_{20} \mathrm{~N}_{16}+60.2 \mathrm{NO}_{3}^{-}= \\
=38.1 \mathrm{~N}_{2}+60.2 \mathrm{HCO}_{3}^{-}+0.8 \mathrm{CO}_{2}+18.4 \mathrm{H}_{2} \mathrm{O} .
\end{gathered}
$$

In Equation (5) the total yield of $\mathrm{N}_{2}$ exceeds $\mathrm{NO}_{3}^{-}$ depletion by $\sim 27 \%$. In addition, to the extent that this equation is correct in suggesting that there is no accompanying release of $\mathrm{PO}_{4}^{3-}, \mathrm{N}_{\text {deficit }}$ would underestimate $\mathrm{N}_{2}$ production by another $\sim 15 \%$. Thus, with no release of $\mathrm{PO}_{4}{ }^{3-}$ we could now account for $\sim 42 \%$ of the "extra excess $\mathrm{N}_{2}$ ", but we doubt that no $\mathrm{PO}_{4}{ }^{3-}$ is released. Instead, we will assume that, with preferential use of amino acids by denitrifiers, we can 
account for $\sim 35 \%$ of the "extra excess $\mathrm{N}_{2}$ ". Codispoti and Christensen (1985) suggest that high rates of $\mathrm{N}_{2} \mathrm{O}$ production during microaerophilic nitrification at the boundaries of suboxic zones could be coupled with reduction to $\mathrm{N}_{2}$ by denitrifiers. This could increase the $\mathrm{N}_{2 \text { produced }} / \mathrm{NO}_{3}^{-}$consumed by another $\sim 3 \%$. In addition, the Arabian Sea, at times, has high nitrogen fixation rates. N/P ratios (by atoms) during nitrogen fixation range from $~ 57-140$ (Gruber and Sarmiento, 1997; Karl et al., 1992) and community $\mathrm{N} / \mathrm{P}$ ratios under these conditions may be $>20$ (Naqvi et al., 1986; Karl et al., 1995) vs the canonical Redfield ratio of 16/1 (by atoms). Thus, if a significant portion of the organic matter supplied to the suboxic zone is supported by nitrogen fixation we could account for an additional fraction of the excess $\mathrm{N}_{2}$. Overall, it is plausible to suggest that these revisions to the stoichiometry could yield a contribution of $\mathrm{N}_{2}$ from the oxidation of organic $\mathrm{N}$ that is equivalent to $\sim 40 \%$ of the contribution from $\mathrm{NO}_{3}^{-}$, but how do we account for the rest?

If sediments contribute $\mathrm{N}_{2}$ or precursors of $\mathrm{N}_{2}$ to the water column without a corresponding contribution of $\mathrm{PO}_{4}^{3}$, a further portion of the discrepancy between $\mathrm{N}_{\text {deficit }}$ and the excess $\mathrm{N}_{2}$ values might be explained. Sedimentary denitrification rate estimates for the Arabian Sea range from 6-20\% of the pelagic rate (Bange et al.; 2000; Uhlenhopp et al., in prep.). A large fraction of this probably occurs in shallow sediments that are in contact with water that can exchange excess $\mathrm{N}_{2}$ with the atmosphere. In addition, although phosphorite deposits are found in margin sediments in contact with low oxygen waters (e.g. Piper and Codispoti, 1975), suggesting that $\mathrm{N}_{2}$ might be released without proportionate $\mathrm{P}$, we (AHD and JAB) have observed anomalously high (and puzzling) releases of $\mathrm{P}$ from sediment underlying suboxic waters. For these reasons, we speculate that, at most, only a few \% of the "extra excess $\mathrm{N}_{2}$ " (not accounted for by $\mathrm{N}_{\text {deficit }}$ ) is likely to come from sedimentary denitrification via the "canonical pathway" that involves coupled nitrification-denitrification (e.g. Seitzinger et al., 1993).

There may be an important additional source of excess $\mathrm{N}_{2}$ that arises from the interactions between the $\mathrm{S}$ and $\mathrm{N}$ cycles described earlier. We have already mentioned that Thioploca, Beggiatoa, and Thiomargarita can transport $\mathrm{NO}_{3}^{-}$into $\mathrm{HS}^{-}$bearing environments and gain energy by using the $\mathrm{NO}_{3}{ }^{-}$to oxidize $\mathrm{HS}^{-} . \mathrm{NH}_{3}$ is the most likely nitrogeneous end-product, but some $\mathrm{N}_{2}$ may be produced, as noted earlier (e.g. during thiosulfate oxidation by
Thiobacillus denitrificans). One should expect high $\mathrm{N} / \mathrm{PO}_{4}{ }^{3-}$ export ratios from such sediments because these bacteria are using energy from $\mathrm{NO}_{3}^{-}$oxidation of $\mathrm{HS}^{-}$compounds to fuel growth instead of the oxidation of $\mathrm{P}$ containing "Redfieldian" organic matter. High rates of $\mathrm{NH}_{3}$ export have been observed from sediments with Thioploca mats off Chile (Farias, 1998), and Thioplaca mats have been observed in the northwest Arabian Sea (Jørgensen and Gallardo, 1999; Levin et al., 1997).

If this $\mathrm{NH}_{3}$ is released into suboxic waters, it may be oxidized to $N_{2}$. We have already mentioned the possibility of microaerophilic production of $\mathrm{N}_{2} \mathrm{O}$ from this $\mathrm{NH}_{3}$ via nitrification followed by denitrification as suggested by Codispoti and Christensen (1985). Other possibilities are suggested by data from the Black Sea (Fig. 8). Examination of fixed N-gradients in the suboxic zone of the Black Sea (Fig. 8) shows that there is an apparent downwards flux of $\mathrm{NO}_{3}{ }^{-}$into the suboxic zone and an upwards flux of $\mathrm{NH}_{3}$. Thus, the major observed forms of fixed-N enter this zone and appear to disappear! To explain this, it has been hypothesized (Codispoti et al., 1991; Murray et al., 1995) that all forms of inorganic $\mathrm{N}$ are converted to $\mathrm{N}_{2}$ in this region. Two possible pathways for these transformations are the "annamox" reaction and reactions facilitated by $\mathrm{Mn}$ redox cycling. In the "annamox" reaction, $\mathrm{NO}_{2}^{-}$(produced from $\mathrm{NO}_{3}^{-}$, in our case) oxidizes $\mathrm{NH}_{3}$ with both species being converted to $\mathrm{N}_{2}$. A bacterium that can carry out the "annamox" reaction has recently been isolated from a biofilm (Strous et al., 1999). Several authors have suggested that oxidation of $\mathrm{NH}_{3}$ by $\mathrm{NO}_{3}^{-}$is thermodynamically possible (e.g. Richards, 1965). In the cycle facilitated by Mn redox processes, Mn (II) is oxidized to $\mathrm{Mn}$ (III, IV) by $\mathrm{NO}_{3}^{-}$which is reduced to $\mathrm{N}_{2}$, and oxidation of $\mathrm{NH}_{3}$ by $\mathrm{Mn}$ (III, IV) also produces $\mathrm{N}_{2}$ (Luther et al., 1997).

Vertical $\mathrm{PO}_{4}{ }^{3-}$ and $\mathrm{HS}^{-}$profiles from the Black Sea (Fig. 8) provide support for this Mn redox cycle. The complex $\mathrm{PO}_{4}{ }^{3-}$ profiles can be explained as follows:

1. a dissolved Fe (II) and Mn (II) flux from the anoxic zone to the suboxic zone,

2. oxidation to $\mathrm{Fe}$ (III) and $\mathrm{Mn}$ (III, IV) by $\mathrm{NO}_{2}^{-}$ and $\mathrm{NO}_{3}^{-}$in the suboxic zone,

3. formation of Fe (III) and Mn (III, IV) containing precipitates that scavenge $\mathrm{PO}_{4}^{3-}$ creating the $\mathrm{PO}_{4}^{3-}$ minimum in the suboxic zone, and

4. formation of the $\mathrm{PO}_{4}{ }^{3-}$ maximum in the upper part of the sulfide zone where the precipitates dissolve (Codispoti et al., 1991a; Murray et al., 1995; Spencer and Brewer, 1971;). 


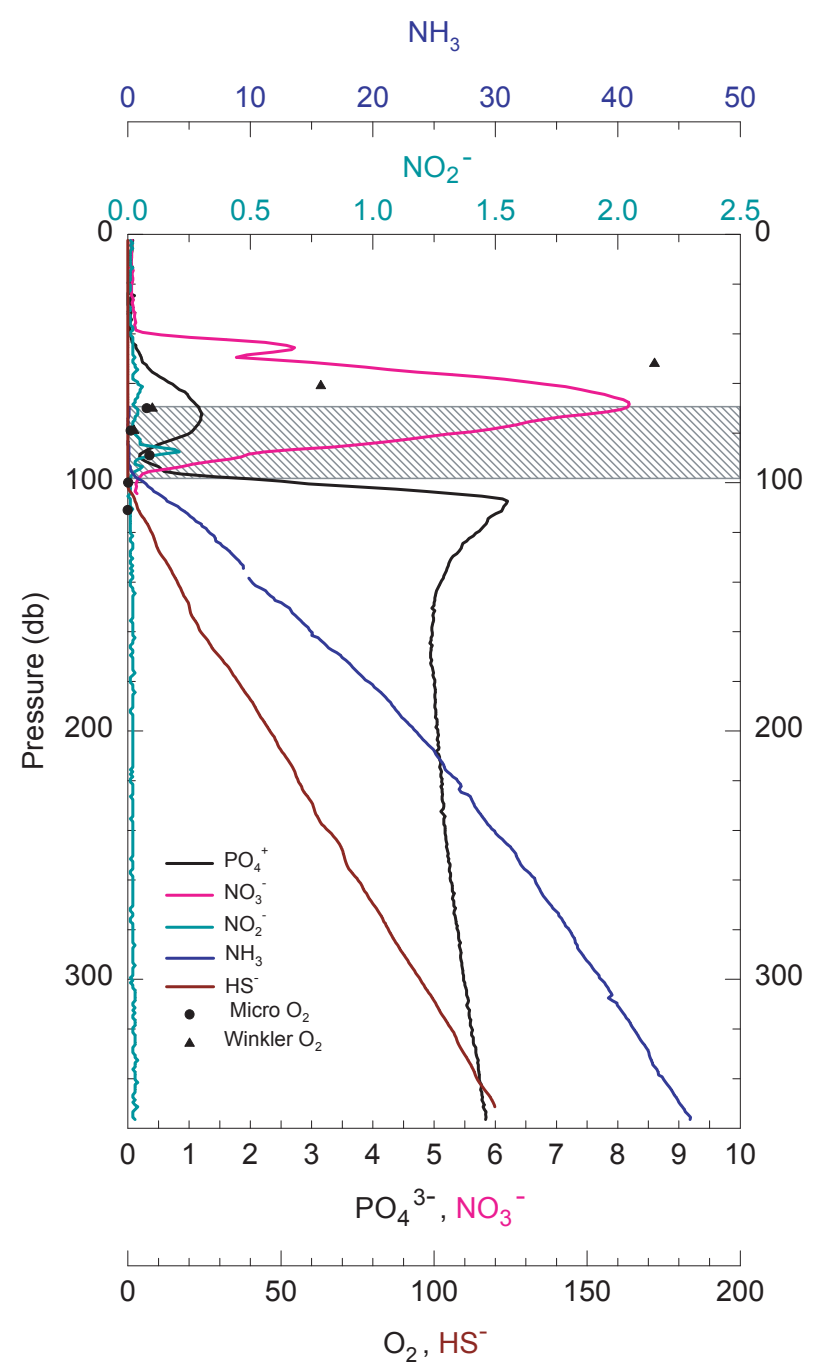

FIG. 8. - Continuous vertical profiles of $\mathrm{NO}_{3}^{-}, \mathrm{NO}_{2}^{-}, \mathrm{NH}_{3}, \mathrm{PO}_{4}^{3-}$ and sulfide $\left(\mathrm{H}_{2} \mathrm{~S}+\mathrm{HS}^{-}+\mathrm{S}^{2-}\right)$ in a pump profile that sampled oxic, suboxic and anoxic portions of the Black Sea's water column. Discrete Winkler and colorimetric dissolved oxygen concentrations taken with the low-concentration method of Broenkow and Cline (1969) are also included. The shaded area denotes the suboxic zone. Sulfide is essentially zero in this zone, and oxygen concentrations are generally less than $5 \mu \mathrm{M}$, although in these data there is one depth within the zone were dissolved oxygen concentrations were $\sim 7 \mu \mathrm{M}$. The low nitrite $\left(\mathrm{NO}_{2}^{-}\right)$concentrations $(\sim 0.01-0.02 \mu \mathrm{M})$ in the anoxic zone are probably artifacts, The nitrite peak near the bottom of the suboxic zone was often more pronounced than in this pump profile (Codispoti et al., 1991a). These data are from (Friederich et al., 1990). Concentrations are in $\mu \mathrm{M}$.

Luther et al. (1997) performed laboratory experiments, compared nitrogen cycling in $\mathrm{Mn}$ rich and $\mathrm{Mn}$ poor sediments, and provided thermodynamic calculations suggesting that such a $\mathrm{N}_{2}$ producing $\mathrm{Mn}$ redox cycle is possible. Since it is likely that both Mn (II) and $\mathrm{NH}_{3}$ are released from sediments underlying suboxic waters, we have another mechanism for producing excess $\mathrm{N}_{2}$. Because $\mathrm{Mn}$ can be re-cycled it functions like a catalyst. Thus, we can write the same stoichiometric equation for both the annamox reaction and the $\mathrm{Mn}-\mathrm{NH}_{3}-\mathrm{NO}_{3}^{-}$redox cycle:

$$
5 \mathrm{NH}_{3}+3 \mathrm{HNO}_{3} \rightarrow 4 \mathrm{~N}_{2}+9 \mathrm{H}_{2} \mathrm{O}
$$

For this reaction, the total $\mathrm{N}_{2}$ produced exceeds the $\mathrm{N}_{2}$ contributed by $\mathrm{NO}_{3}^{-}$by $167 \%$. Clearly, to the extent that there are fluxes of $\mathrm{NH}_{3}$ that are coupled to energy production from the $\mathrm{NO}_{3}^{-}-\mathrm{HS}^{-}$couple and not to remineralization of P-containing organic matter, we have the potential for a reaction that could contribute powerfully to the pool of "extra excess $\mathrm{N}_{2}$ " (Fig. 7). We should also note that Luther et al. (1997) point out that oxidation of organic matter by $\mathrm{MnO}_{2}$ produces $\mathrm{N}_{2}$ and that this under-appreciated pathway for $\mathrm{N}_{2}$ production may enhance sedimentary denitrification rates in $\mathrm{Mn}$ rich sediments. Lewis and Luther (2000) found elevated Mn concentrations at mid-depths in the Arabian Sea's suboxic waters suggesting that the catalytic Mn redox cycle may occur there as well. Maximum values were $\sim 8 \mathrm{nM}$, so the quantitative significance of this process away from the sediments may be small even though the Mn can be recycled. Moreoever, the yield of "extra excess $\mathrm{N}_{2}$ " will be smaller than suggested in Equation 6 because, at mid-depths, the cycle is likely to be fueled largely by organic matter, not $\mathrm{NH}_{3}$.

Farrenkopf et al. (1997a, b) have shown that bacteria can use $\mathrm{IO}_{3}{ }^{-}$to oxidize organic matter and gain a similar amount of free energy as gained from the use of $\mathrm{NO}_{3}^{-}$. This is another process that could produce $\mathrm{N}_{2}$ (from organic $\mathrm{N}$ ) without consuming $\mathrm{NO}_{3}^{-}$. The bacteria convert $\mathrm{IO}_{3}^{-}$to $\mathrm{I}^{-}$, and Farrenkopf et al. found that maximum $\mathrm{I}^{-}$concentrations in the suboxic waters of the Arabian Sea approach $1 \mu \mathrm{M}$. Based on Equation (5) and an oxidation state change from $+\mathrm{V}$ to $-\mathrm{I}$, it is possible that $\mathrm{IO}_{3}^{-}$reduction could produce $\sim 0.3 \mu$ g-atoms of $\mathrm{N}_{2}$, about $3 \%$ of the maximum "extra excess $\mathrm{N}_{2}$ " values (Fig. 7). Of course, for this process or the water column Mn redox cycle to account for $\mathrm{N}_{2}$ production not already included in $\mathrm{N}_{\text {deficit }}, \mathrm{PO}_{4}^{3-}$ releases would have to be low.

Overall, there are several processes that could contribute to the "extra excess $\mathrm{N}_{2}$ ". We believe that these data imply that existing estimates of water column denitrification are too low.

\section{The oceanic $\mathrm{N}_{2} \mathrm{O}$ regime}

In addition to its importance as an intermediate in the nitrogen cycle, $\mathrm{N}_{2} \mathrm{O}$ is an important trace gas that is increasing in the atmosphere. Depending on the chosen time frame, $\mathrm{N}_{2} \mathrm{O}$ (per molecule) has a global warming potential 170 to 310 times greater than $\mathrm{CO}_{2}$ (Manne and Richels, 2001). It adds several percent 
to the greenhouse effect under present-day conditions and plays a role in the destruction of stratospheric ozone (Andreae and Crutzen, 1997; Nevison and Holland, 1997). The ocean is a net source of $\mathrm{N}_{2} \mathrm{O}$ to the atmosphere but there is a wide range in the estimates. A widely accepted value is Nevinson et al.'s (1995) estimate of $\sim 4 \mathrm{Tg} \mathrm{N} \mathrm{yr}^{-1}$ (Table 1) with a range of 1.2-6.8 $\mathrm{Tg} \mathrm{N} \mathrm{yr}^{-1}$. Bange et al. (1996) suggest that some estimates did not sufficiently account for high $\mathrm{N}_{2} \mathrm{O}$ concentrations found in coastal and upwelling regions and estimate the oceanic source, excluding estuaries, as 4.5-7.4 Tg N $\mathrm{yr}^{-1}$. A biologically constrained approach yielded an estimate of $\sim 10.5 \mathrm{Tg} \mathrm{N} \mathrm{yr}^{-1}$ for the open ocean and coastal regions (Capone, 1991).

Because $\mathrm{N}_{2} \mathrm{O}$ production and consumption are enhanced at low oxygen concentrations (Codispoti and Christensen, 1985; Codispoti et al., 1992; Goreau et al., 1980; Suntharalingam et al., 2000), the distribution of $\mathrm{N}_{2} \mathrm{O}$ in the ocean is highly non-uniform. Indeed, the highest and lowest concentrations, can often be found in close proximity with the lowest values occurring in the core of suboxic zones or in anoxic zones and the highest values occurring at the boundaries of suboxic zones (Codispoti et al., 1986; Law and Owens, 1990; Naqvi and Noronha, 1991; Naqvi et al., 2000, Pierotti and Rasmussen, 1980; Yoshinari et al., 1997). Results from the ETSP (Codispoti et al., 1992) and the Arabian Sea (Naqvi et al., 2000) where such conditions exist suggest that $\mathrm{N}_{2} \mathrm{O}$ saturations in excess of $1000 \%$ can be found at the sea surface. Bange et al. (2000), Law and Owens (1990) and Naqvi and Noronha (1991) suggest that this situation leads to globally significant transport of $\mathrm{N}_{2} \mathrm{O}$ from the Arabian Sea to the atmosphere, despite this region's small area ( $2 \%$ of the oceanic total). Recently, Naqvi et al. (2000a) have reported record high $\mathrm{N}_{2} \mathrm{O}$ concentrations during seasonal development of upwelling and low oxygen conditions over the western Indian shelf. Maximum values were $>500 \mathrm{nM}$, and the maximum surface value was $436 \mathrm{nM}$, or $8,250 \%$ saturation. Given that open ocean surface $\mathrm{N}_{2} \mathrm{O}$ saturation values are generally less than $105 \%$, the high surface values observed off Peru and India demonstrate the highly non-linear distribution of oceanic $\mathrm{N}_{2} \mathrm{O}$.

Although nitrification at low oxygen concentrations could contribute to the high values on the western Indian shelf, Naqvi et al. (2000a) suggest that the major contributor is "stop and go" denitrification. Laboratory experiments, suggest that nitrous oxide reductase is slow to be induced relative to the other enzymes involved in denitrification, and some stud- ies suggest that it is relatively susceptible to oxygen inhibition (Dendooven and Anderson, 1994; Firestone and Tiedje, 1979). Thus, a portion of the high $\mathrm{N}_{2} \mathrm{O}$ values found at the boundaries of suboxic zones probably arises from denitrification that is in the "spin-up" phase (Codispoti et al., 1992). In the shallow waters studied by Naqvi et al. (2000a), there were strong gradients, with conditions varying from oxic to anoxic. In addition, meteorological events should have a strong influence on these shallow waters. Thus, the conditions are ripe for "stop and go" denitrification. Naqvi et al. (2000a) suggest that the $\mathrm{N}_{2} \mathrm{O}$ flux to the atmosphere arising from these conditions is 0.04-0.25 Tg N yr-1. Bange et al. (2000) suggest an average value for the Arabian Sea of 0.4 $\mathrm{Tg} \mathrm{N} \mathrm{yr}{ }^{-1}$ not including the high $\mathrm{N}_{2} \mathrm{O}$ values observed by Naqvi et al. (2000a). Considering the wide range of estimates, and as yet undiscovered $\mathrm{N}_{2} \mathrm{O}$ "hotspots" that may occur during upwelling off Oman, one can speculate that the $\sim 2 \%$ of the global oceanic area represented by the Arabian Sea might provide $\sim 1 \mathrm{Tg} \mathrm{N}$ $\mathrm{yr}^{-1}$ of $\mathrm{N}_{2} \mathrm{O}$ to the atmosphere under present-day conditions, a significant fraction of the global oceanic total (Table 1). To our knowledge, observations of other seasonal low oxygen zones that develop over other shelves such as the "dead zone" off the mouth of the Mississippi River (Rabalais et al., 2000) have not been examined for their potential impact on oceanic $\mathrm{N}_{2} \mathrm{O}$ emissions.

\section{DISCUSSION}

\section{Perspective}

The major goal of this paper is not to provide definitive answers vis a vis the oceanic fixed $\mathrm{N}$ budget and $\mathrm{N}_{2} \mathrm{O}$ cyling, but to suggest that prior studies (including some of our own!) suffer from a rigidity imposed by a tendency to prefer budgets that balance and systems that are in a steady-state. So far, we have suggested that many traditional estimates of the oceanic water-column denitrification rate (including our own) are too low and that prevailing estimates of $\mathrm{N}_{2} \mathrm{O}$ emissions from the ocean (Table 1) may also be low. We think that our upwards revisions are conservative, but given the present state of knowledge, our revised estimates are speculative. We use them not to provide a rigorous budget, but to show that prevailing budgets (e.g. Codispoti and Christensen, 1985; Table 1) may be misleading and that we might not be asking the right questions. 
An oceanic denitrification rate of $>400 \mathrm{Tg} \mathrm{N} \mathrm{yr}^{-1}$ ?

Our data suggest that $\mathrm{N}_{\text {deficit }}$ underestimates the excess $\mathrm{N}_{2}$ burden in the water column by a factor of $\sim 2$ (Fig. 7), and that some prior nitrate deficit and denitrification rate estimates based on NTO relationships underestimate the excess $\mathrm{N}_{2}$ burden by a factor of $\sim 4$ (Compare Figs. 4 and 7). Similarly, estimates of denitrification based on ETS activities (Codispoti and Packard, 1980; Codispoti et al., 1986; Naqvi and Shailaja, 1993) did not account for the higher ratios of $\mathrm{N}_{2}$ production to $\mathrm{NO}_{3}^{-}$consumption during denitrification suggested by our Arabian Sea data (Fig. 7). In addition, they may have been applied to volumes that were too small due to the assumption that denitrification was important only in suboxic waters with $\mathrm{NO}_{2}^{-}$ concentrations $>0.2-0.5 \mu \mathrm{M}$.

Although there is a wide range in recent denitrification rate estimates for the Arabian Sea water column (10-44 $\mathrm{Tg} \mathrm{N} \mathrm{yr}^{-1}$, Uhlenhopp et al., in prep.), for a variety of reasons we believe that a value of $\sim 30 \mathrm{Tg}$ $\mathrm{N} \mathrm{yr}^{-1}$ is reasonable for the $\mathrm{NO}_{3}^{-}$consumption portion of the denitrification rate, in agreement with the recent results of Bange et al. (2000). Since water column burdens of excess $\mathrm{N}_{2}$ exceed traditional NTO based nitrate deficit estimates by a factor of 4 (Fig. 7), it might seem reasonable to quadruple the existing estimate of $\sim 30 \mathrm{Tg} \mathrm{N} \mathrm{yr}^{-1}$ in order to account for the additional sources of $\mathrm{N}_{2}$ that we have discussed. A significant portion of the "extra excess $\mathrm{N}_{2}$ ", however, occurs in the deeper portion of the water column where water residence times are likely to be longer. Therefore, for the purposes of this discussion, we will assume that a reasonable estimate for water column denitrification in the Arabian Sea's "permanently" suboxic portion of the OMZ is twice the "traditional" estimate, or $60 \mathrm{Tg} \mathrm{N} \mathrm{yr}{ }^{-1}$.

Our prior estimates for the denitrification rate in the suboxic portions of the OMZ in the ETNP and ETSP total $\sim 50 \mathrm{Tg} \mathrm{N} \mathrm{yr}^{-1}$ (Codispoti, 1989). The estimate for the ETSP included some transient sites on the margin of the "permanent" suboxic zone (Codispoti and Packard, 1980). Assuming that the methods used to estimate nitrate deficits in the Pacific adequately accounted for $\mathrm{NO}_{3}{ }^{-}$removals, we might expect water column burdens of excess $\mathrm{N}_{2}$ to exceed nitrate deficits by a factor of $\sim 2$, a conclusion that is supported by some preliminary excess $\mathrm{N}_{2}$ data from the ETNP (Brandes et al., 1996). We will assume, therefore, that it is conservative to increase our previous estimates of water column denitrification in this region by $50 \%$ and to suggest that the true value in today's ocean is closer to $75 \mathrm{Tg} \mathrm{N} \mathrm{yr}^{-1}$. Thus, we arrive at a total rate for the three largest suboxic portions of the oceanic water column of 135 $\mathrm{Tg} \mathrm{N} \mathrm{yr}{ }^{-1}\left(60+75 \mathrm{Tg} \mathrm{N} \mathrm{yr}^{-1}\right)$.

We must also account for the contributions of the smaller/more transient sites of water column denitrification mentioned earlier. Based on the data in Naqvi et al. (2000a), Naqvi et al. (2000b) have estimated a denitrification rate for the seasonal hypoxic/suboxic/anoxic zones over the western Indian Shelf to be $\sim 5 \mathrm{Tg} \mathrm{N} \mathrm{yr}^{-1}$. Estimates for similar sites such as one that develops off the mouth of the Mississippi River (Rabalais et al., 2000) are not available, but given the increase in such sites (Malakoff, 1998) in recent decades, it might be conservative to suggest a total denitrification rate of $>5 \mathrm{Tg} \mathrm{N} \mathrm{yr}^{-1}$, for all such regions. An examination of the size of the suboxic zone off SW Africa (Calvert and Price, 1971) suggests that this region could also contribute

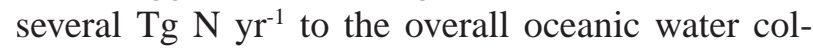
umn denitrification rate. Existing water column denitrification estimates for the Baltic Sea, Cariaco Trench and Black Seas total no more than $0.5 \mathrm{Tg} \mathrm{N}$ $\mathrm{yr}^{-1}$, (Cline, 1973; Goering et al., 1973; Rönner, 1983) but they must be adjusted upwards for the same reasons that we have adjusted the Pacific and Arabian Sea estimates upwards. In addition, anthropogenic impacts have increased maximum $\mathrm{NO}_{3}^{-}$ concentrations in the Black Sea in recent decades and the thickness of the suboxic zone may have increased (Codispoti et al., 1991a; Murray et al., 1989), so the older estimates for the Black Sea could be massive underestimates. All in all, we think it reasonable to suggest that a conservative estimate for the additional sites of oceanic suboxic water column denitrification would be $\sim 10 \mathrm{Tg} \mathrm{N} \mathrm{yr}^{-1}$.

There is another potential contributor to the oceanic water column denitrification rate about which we know next to nothing, the possibility of denitrification in oxygenated waters and within microenvironments in oxygenated waters (Tsunogai, 1971; Yoshinari and Koike, 1994). Some studies suggest the presence of denitrification in microenvironments (Alldredge and Cohen, 1987; Wolgast et al., 1998), but they do not allow us to scale up to a global rate for oxygenated waters. Remember, however, that the identified water column sites of denitrification comprise only $\sim 0.1 \%$ of the total oceanic volume. Thus, an extremely small rate of $\mathrm{N}_{2}$ production in oxygenated waters by any of the processes that we have mentioned could add significantly to the total oceanic water column rate. Laboratory 
experiments (Lloyd, et al., 1987) suggest that $\mathrm{N}_{2}$ production by denitrifiers can persist in the presence of oxygen in excess of $100 \mu \mathrm{M}$. In addition, the energetics of oxidation of organic matter under oxic conditions by Mn (IV) compares favorably with direct oxidation, and the organic $\mathrm{N}$ oxidized by $\mathrm{Mn}$ (IV) may be converted to $\mathrm{N}_{2}$ (Froelich et al., 1979; Luther et al., 1998). Overall, it seems that we can conservatively estimate a water column denitrification rate in the present-day ocean of $\sim 150 \mathrm{Tg} \mathrm{N} \mathrm{yr}^{-1}$.

Middleburg et al. (1996) suggest an oceanic sedimentary denitrification rate between $230-285 \mathrm{Tg} \mathrm{N}$ $\mathrm{yr}^{-1}$ based on canonical stoichiometries similar to those that underestimate water column production of $\mathrm{N}_{2}$. This estimate could, therefore, be conservative, particularly, since the potential importance of $\mathrm{Mn}$ redox processes to sedimentary production of $\mathrm{N}_{2}$ has not received sufficient attention as noted by Luther et al. (1997). In addition, consideration of the isotopic composition of oceanic $\mathrm{NO}_{3}{ }^{-}$suggests that the sedimentary rate, on average, should exceed the water column production of $\mathrm{N}_{2}$ from $\mathrm{NO}_{3}^{-}$by several times (Brandes, 1996). This argument needs refinement due to the changing nature of our understanding of sources, sinks and pathways, but the essentials are as follows. Oceanic $\mathrm{NO}_{3}{ }^{-}$has a $\delta^{15} \mathrm{~N}$ of $\sim+5 \%$ (Sigman et al., 1999), and this value arises from a balance of the inputs and losses. Neglecting the minor terms, the major input is nitrogen fixation, which produces fixed nitrogen with a $\delta^{15} \mathrm{~N}$ of $\sim 0 \%$ o (Hoering and Ford, 1960; Minagawa and Wada, 1986), and the major losses are water column and sedimentary denitrification. Water column denitrification, which in most suboxic zones occurs with only partial depletion of the $\mathrm{NO}_{3}^{-}$pool, removes $\mathrm{NO}_{3}{ }^{-}$with a $\delta^{15} \mathrm{~N}$ of $\sim-20 \%$ (Brandes et al., 1998). In contrast, the isotopic fractionation during sedimentary denitrification is small and removes fixed $\mathrm{N}$ with a $\delta^{15} \mathrm{~N}$ of $\sim 3 \%$. We will assume that the processes that produce the "extra excess $\mathrm{N}_{2}$ " observed in suboxic waters also removes fixed $\mathrm{N}$ with a $\delta^{15} \mathrm{~N}+3 \%$. Therefore, for the isotopic composition of the overall denitrification loss to match that of the nitrogen fixation input ( $\sim \%$ ) , the overall denitrification rate would need to be about 8 times larger than the water column rate of nitrate removal by denitrification (i.e. $\{6.7 x(+3)\}+(-20)=$ $0)$. One eighth is, of course accounted for by water column conversion of $\mathrm{NO}_{3}^{-}$to $\mathrm{N}_{2}$. Another $1 / 8$ would also come from water column processes since the water column burden of excess $\mathrm{N}_{2}$ values in the suboxic portions of the Arabian Sea (Fig. 7) is about twice the $\mathrm{N}_{\text {deficit }}$ burden, indicating that processes other than $\mathrm{NO}_{3}^{-}$reduction produce about $1 / 2$ the excess $\mathrm{N}_{2}$. The remaining 3/4 would come from sedimentary denitrification and would amount to $6 \times 75$ or $450 \mathrm{Tg} \mathrm{N} \mathrm{yr}^{-1}$. In addition to the preliminary nature of the isotopic argument, a possible weakness is that it is true only for periods long enough for us to assume a steady-state budget with respect to the $\delta^{15} \mathrm{~N}$ of oceanic $\mathrm{NO}_{3}^{-}$. This may not be the case as we enter the Anthropocene. We employ the isotopic data, at this point, only to demonstrate that they do not contradict the assertion that our selected rate of $300 \mathrm{Tg} \mathrm{N} \mathrm{yr}^{-1}$ for sedimentary denitrification (Table 1) could be conservative.

How can we reconcile our total denitrification rate for continental shelves and the open ocean of $450 \mathrm{Tg} \mathrm{N} \mathrm{yr}{ }^{-1}$ with the other budget terms (Table 1)? Perhaps the simplest explanation is that the presentday oceanic $\mathrm{N}$ budget is more or less in balance, but we have underestimated the source terms. We have already adjusted the anthropogenic source terms upwards (Table 1) and noted that the atmospheric anthropogenic DON term and groundwater inputs (e.g. Krest et al., 2000) are poorly documented. Reasonable increases in atmospheric, runoff and groundwater inputs appear, however, to be unlikely to completely balance the budget. If the budget is to be balanced, the oceanic nitrogen fixation term will have to be increased. A conundrum is that even Gruber and Sarmiento's (1997) estimate for oceanic nitrogen fixation of $125 \mathrm{Tg} \mathrm{N} \mathrm{yr}^{-1}$ (Table 1) is high in relation to the results of direct incubations (e.g. Lipshultz and Owens, 1996). Studies of primary production rates in the Arctic are, however, instructive with regard to this type of a discrepancy between rates estimated from incubations and rates estimated from water mass properties. Traditional incubation-based estimates for Arctic primary production are lower than many estimates based on water mass properties (Codispoti et al., 1991b). In the case of the Arctic, the discrepancy arose, in part, because many incubation studies were conducted in the post-bloom period when ice conditions were most favorable to navigation. Since primary productivity events in the Arctic tend to be localized, it is also easy to miss peak events. Water mass properties integrate over time and space and are not as subject to these problems. In addition, most studies of oceanic nitrogen fixation have concentrated on Trichodesmium, yet there are many other species that may have the ability to fix N. Finally, the incubations employed to obtain nitrogen fixation rates are 
highly subject to experimental artifacts (Paerl, 1990; Paerl and Zehr, 2000). We suggest that it is possible that the oceanic nitrogen fixation rate is considerably higher than present estimates.

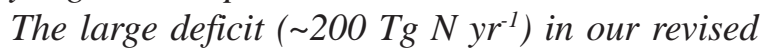
oceanic fixed-N budget (Table 1) could also arise because all studies bearing on this subject have been made during the climatic transition from the Holocene to the Anthropocene. Thus, our observations were taken from a "moving target". How do we combine observations taken over several decades if we are in a period of rapid change? In addition, large imbalances are certainly possible during rapid transition. Firstly, there would be effects due to changes in circulation and stratification that are related to climate change, per se. For example, anthropogenic activities may be increasing the frequency of major El Niño/La Niña cycles, and we have already noted that an acceleration of the denitrification rate in the ETSP was noted during the 1985 Niña (Codispoti et al., 1986). Recently, a combination of development and increased hurricane frequency have led to large pulses of fixed $\mathrm{N}$ to the North Carolina coastline (Paerl et al., 2000, 2001). We have already mentioned increases in coastal hypoxia/anoxia, and the increase in maximum $\mathrm{NO}_{3}{ }^{-}$concentrations in the Black Sea. In mentioning, the two accelerations of denitrification off Peru, we noted that one followed the collapse of the Peruvian anchoveta fishery (Codispoti and Packard, 1980). We know of no other studies that have attempted to relate fishing pressure to oceanic denitrification rates, but we do know that fishing pressure has massively influenced oceanic ecosystems. Margalef (1974) and Watling and Norse (1998) have, for example, commented on major ecosystem changes arising from bottom trawling. Overall, we believe that more attention must be given to how climate change and more direct anthropogenic impacts alter the oceanic fixed $N$ regime.

Our revised budget (Table 1) and a similar budget by Middleburg et al. (1996) produce a much shorter turnover time for oceanic fixed $\mathrm{N}$ (Table 2) and a significant reduction in the oceanic biological pump's ability to sequester atmospheric $\mathrm{CO}_{2}$ because of decreases in fixed N. Multiplying the deficit in our budget by a Redfield $\mathrm{C} / \mathrm{N}$ ratio of 6.6 (by atoms) gives a $\sim 1.310^{15} \mathrm{~g}$ of $\mathrm{C} \mathrm{yr}^{-1}$ potential reduction in oceanic new primary production. Given the present state of knowledge, the fixed $\mathrm{N}$ deficit in our budget could be much smaller or much larger. It is also likely that these values are changing. Until we better understand how far out of balance anthro-
TABLE 2. - An unauthorized history of minimum turnover time estimates for oceanic fixed-N (Inventory/Total Sink Term)

\begin{tabular}{lr}
\hline Author(s) & Years \\
\hline Brandt (1899) & 2 \\
1930 estimate quoted by Harvey (1960) & 10,000 \\
Emery, Orr and Rittenburg (1955) & 10,000 \\
Eriksson (1959) & 10,000 \\
Tsunogai \& Ikeuchi (1968) & 4,000 \\
Tsunogai (1971) & 26,000 \\
Codispoti (1973) & 8,000 \\
Liu (1979) & 8,000 \\
Codispoti \& Christensen (1985) & 5,000 \\
Capone (1991) & 3,500 \\
Codispoti (1995) & 3,000 \\
Middleburg et al. (1996) & 2,300 \\
Gruber and Sarmiento (1997) & 3,500 \\
This paper & 1,500 \\
And going lower??? & \\
\hline
\end{tabular}

pogenic activities might drive the oceanic fixed $N$ budget, we cannot neglect its potential influence on atmospheric $\mathrm{CO}_{2}$ concentrations.

\section{Potential for change in the oceanic nitrous oxide source term}

On a per molecule basis, $\mathrm{N}_{2} \mathrm{O}$ is $\sim 200-300$ times more powerful than $\mathrm{CO}_{2}$ (Manne and Richels, 2001) as a greenhouse gas, and increases in $\mathrm{N}_{2} \mathrm{O}$ contribute to the destruction of stratospheric ozone (Nevison and Holland, 1997). Thus, trying to understand how the oceanic source term for $\mathrm{N}_{2} \mathrm{O}$ may change as we enter the Anthropocene is of more than casual interest. We have revised the prevailing oceanic $\mathrm{N}_{2} \mathrm{O}$ source term upwards by $2 \mathrm{Tg} \mathrm{N} \mathrm{yr}^{-1}$ in our oceanic fixed $\mathrm{N}$ budget (Table 1) to account for the expansion of low oxygen conditions in coastal regions (e.g. Naqvi et al., 2000a). Once again, at the present state of knowledge we could argue about whether this revision should be larger or smaller, but to do so misses the more important question of how this term might change. We know that the highest $\mathrm{N}_{2} \mathrm{O}$ concentrations are found near the boundaries of suboxic waters (Codispoti et al., 1992) and that in the "stop and go" denitrification regime found off the western Indian shelf surface concentrations can achieve saturations in excess of $8,000 \%$ (Naqvi et al., 2000a). We also know that, with some exceptions such as the California Borderland Basins (Stott et al., 2000), suboxia in coastal regions is on the increase and that only small changes in carbon and nutrient fluxes, and circulation (e.g. Codispoti, 1989) could cause significant increases in oceanic suboxia and $\mathrm{N}_{2} \mathrm{O}$ cycling (Codispoti and Chris- 
tensen, 1985). Finally, we note that the time scale for change in the oceanic $\mathrm{N}_{2} \mathrm{O}$ regime is relatively short. The oceanic inventory of $\mathrm{N}_{2} \mathrm{O}$ is $\sim 1000 \mathrm{Tg} \mathrm{N}$ (Suntharalingam et al., 2000) and dividing by our source term of $6 \mathrm{Tg} \mathrm{N} \mathrm{yr}^{-1}$ (Table 1) gives a turnover time of $<200$ years. Most of this turnover probably occurs in the upper $1000 \mathrm{~m}$ of the water column, so it might be fair to say that the inherent time scale for change is closer to 50 years.

Ice core observations (Flückiger et al., 1999; Leuenberger and Siegenthaler, 1992) suggest that variations in atmospheric $\mathrm{N}_{2} \mathrm{O}$ during the last Glacial - Holocene moved roughly in concert with $\mathrm{CH}_{4}$ and that each gas contributed about $15 \%$ to greenhouse forcing during the Glacial - Postglacial transition. Although the concentrations of $\mathrm{CO}_{2}, \mathrm{CH}_{4}$ and $\mathrm{N}_{2} \mathrm{O}$ were all lower during the Glacial, there are significant departures in the trends for each gas. Present-day $\mathrm{N}_{2} \mathrm{O}$ concentrations are unprecedented in the last $45 \mathrm{kyr}$. Of perhaps greater interest, are some spikes in the record that have not yet been fully explained. Given a time-scale of $\sim 50$ yrs, the potency of $\mathrm{N}_{2} \mathrm{O}$ as a greenhouse gas, and the expansion of coastal suboxia, can we be in for some surprises vs the oceanic $\mathrm{N}_{2} \mathrm{O}$ source as we enter the Anthropocene?

\section{Some cautionary riddles}

As we enter the Anthropocene, we are likely to hear more and more schemes advanced to engineer global climate, including Fe fertilization of the ocean. Some of the potential downside effects of Fe fertilization on the oceanic $\mathrm{N}$ cycle have already been described (e.g. Fuhrman and Capone, 1991). Here are three "cautionary riddles" that the reader can solve based on the information already presented:

1. If you want to make the ocean more Fe limited, add $\mathrm{Fe}$ in the wrong place.

2. If you want to make the ocean more $\mathrm{N}$ limited add fixed $\mathrm{N}$ in the wrong place.

3. If you want to increase greenhouse forcing try to decrease it by adding $\mathrm{Fe}$ to the ocean in the wrong place.

\section{NOTE ADDED IN PROOF}

Recently, Sañudo-Wilhelmy et al. (2001) have suggested that the Fe requirement for nitrogen fixation may have been considerably overestimated in prior studies. Thus, the $\sim 60$ times greater Fe requirement for nitrogen fixation in comparison to $\mathrm{NO}_{3}^{-}$ uptake that we have employed when asserting that denitrification may make the ocean more Fe limited may be too high. A close reading of Sañudo-Wilhelmy et al. (2001) together with information provided by Brand (1991) and Raven (1988), still suggests to us that the $\mathrm{Fe}$ requirement for $\mathrm{NO}_{3}{ }^{-}$uptake by open ocean eukaryotic phytoplankton will prove to be significantly less than for nitrogen fixation, so we still believe that it is reasonable to assert that denitrification may make the ocean more Fe limited, although the Sañudo-Wilhelmy et al. (2001) paper weakens our argument a bit. These authors studied a relatively $\mathrm{Fe}$ rich portion of the Atlantic and found that nitrogen fixation was highly correlated to the $\mathrm{P}$ content of Trichodesmium and was enhanced at higher irradiance. This is in line with previous studies summarized in the main body of our text that suggest that $\mathrm{PO}_{4}^{3-}$ may limit nitrogen fixation in some cases and that the energy requirements for nitrogen fixation are high. Finally, please note that the data for station N-8 in Figure 7 were calculated using a preliminary data set and are too low by about 1.5 micromolar.

\section{ACKNOWLEGEMENTS}

The authors gratefully acknowledge financial support from the National Institute of Oceanography (India), and from the following U.S. agencies: EPA, NOAA, NSF, ONR and the New York State Department of Health. We thank the captains and crews of the research vessels who facilitated our observations, and the many colleagues who have generously shared ideas and advice. We also thank E. Cooper, S. Gaurin, J. Hawkey, E. Haberken and V. Kelly for their hard work in assisting with the preparation of this manuscript. We extend, particular thanks to Professor Ramón Margalef, whose ideas, and example have been a constant inspiration.

\section{REFERENCES}

Alldredge, A.L. and Y. Cohen. - 1987. Can microscale chemical patches persist in the sea? Microelectrode study of marine snow, fecal pellets. Science, 235: 689-691.

Alley, R.B., R.C. Finkel, K. Nishiizumi, S. Anandakrishnan, C.A. Shuman, G. Mershon, G.A. Zielinski and P.A. Mayewski. 1995. Changes in continental and sea-salt atmospheric loadings in central Greenland during the most recent deglaciation Model- based estimates. J. Glaciol., 41: 503-514.

Altabet, M.A., R. Francois, D.W. Murray and W.L. Prell. - 1995. Climate-related variations in denitrification in the Arabian Sea from sediment ${ }^{15} \mathrm{~N} /{ }^{14} \mathrm{~N}$ ratios. Nature, 373: 506-509.

Anderson, L.A. - 1995. On the hydrogen and oxygen content of marine phytoplankton. Deep-Sea Res. Part I. 42: 1675-1680. 
Anderson, J.J., A. Okubo, A.S. Robbins and F.A. Richards. - 1982. A model for nitrite and nitrate distributions in oceanic oxygen minimum zones. Deep-Sea Res. Part A, 29: 1113-1140.

Andreae, M.O. and P.J. Crutzen. - 1997. Atmospheric aerosols: Biogeochemical sources and role in atmospheric chemistry. Science, 276: 1052-1058.

Bange, H.W., S. Rapsomanikis and M.O. Andreae. - 1996. Nitrous oxide in coastal waters. Glob. Biogeochem. Cycle., 10: 197-207.

Bange, H.W., T. Rixen, A.M. Johansen, R.L. Siefert, R. Ramesh, V. Ittekkot, M.R. Hoffmann and M.O. Andreae. - 2000. A revised nitrogen budget for the Arabian Sea. Glob. Biogeochem. Cycle., 14: 1283-1297.

Bolin, B., P. Crutzen, P.M. Vitousek, R.G. Woodmansee, E.D. Goldberg and R.B. Cook. - 1983. The major biogeochemical cycles and their interactions. In: B. Bolin and R.B. Cook (eds.), The major biogeochemical cycles and their interactions, pp. 139. John Wiley \& Sons, New York.

Brand, L.E. - 1991. Minimum iron requirements of marine phytoplankton and the implications for the biogeochemical control of new production. Limnol. Oceanogr. 36(8): 1756-1771.

Brandes, J.A. - 1996. Isotopic effects of denitrification in the marine environment. Ph. D. thesis. Univ. Washington.

Brandes, J.A., A.H. Devol, T. Yoshinari, D.A. Jayakumar and S.W.A. Naqvi. - 1998. Isotopic composition of nitrate in the central Arabian Sea and eastern tropical North Pacific: A tracer for mixing and nitrogen cycles. Limnol. Oceanogr., 43: 1680-1689.

Brandt, K. - 1899. Uber den stoffwechsel im meere. Komm. z Wissensch.Untersuch. Deutschen Meere in Kiel und d. Biologischen Anstalt auf Helgoland. Wissensch. Meeresuntersuch., N.F., Abt. Kiel, 4: 213-230.

Broecker, W.S. and G.M. Henderson. - 1998. The sequence of events surrounding Termination II and their implications for the cause of glacial-interglacial $\mathrm{CO}_{2}$ Changes. Paleoceanography, 13: 352-364.

Broecker, W.S. and T.H. Peng. - 1982. Tracers in the Sea. Eldigio Lamont-Doherty Geology Observatory. Palisades, New York.

Broenkow, W.W. and J.D. Cline. - 1969. Colorimetric determination of dissolved oxygen at low concentrations. Limnol. Oceanogr., 14 (3): 450-454.

Bruland, K., J.R. Donat and D.A. Hutchins. - 1991. Interactive influences of bioactive trace metals on biological production in oceanic waters. Limnol. Oceanogr. 36: 1555-1577.

Butler, J.H. and L.I. Gordon. - 1986. An improved gas chromatographic method for the measurement of hydroxylamine in marine and fresh waters. Mar. Chem., 19: 229-243.

Calvert, S.E. and N.B. Price. - 1971. Upwelling and nutrient regeneration in the Benguela current, October 1968. Deep-Sea Res., 18: $505-523$

Capone, D.G. - 1991. Aspects of the marine nitrogen cycle with relevance to the dynamics of nitrous and nitric oxide. In: J. E. Rodgers and W. B. Whitman (eds.), Microbial production and consumption of greenhouse gases: Methane, nitrogen oxides, and halomethanes, pp. 255-275. American Society for Microbiology, Washington DC

Capone, D.G. and M.F. Bautista. - 1985. A groundwater source of nitrate in nearshore marine sediments. Nature, 313: 214-216.

Capone, D.G., J.P. Zehr, H.W. Paerl, B. Bergman and E.J. Carpenter. - 1997. Trichodesmium, a globally significant marine cyanobacterium. Science, 276: 1221-1229.

Carpenter, E.J. and K. Romans. - 1991. Major role of the cyanobacterium Trichodesmium in nutrient cycling in the North Atlantic Ocean. Science, 254: 1356-1358.

Christensen, J.P., J.W. Murray, A.H. Devol and L.A. Codispoti. 1987. Denitrification in continental shelf sediments has major impact on the oceanic nitrogen budget. Global Biogeochem. Cycle., 1: 97-116.

Cline, J.D. - 1973. Denitrification and isotopic fractionation in two contrasting marine environments: The eastern tropical North Pacific Ocean and the Cariaco Trench. Ph. D. thesis. Univ. Cal. Los. Angles.

Cline, J.D. and F.A. Richards. - 1972. Oxygen deficient conditions and nitrate reduction in the eastern tropical North Pacific Ocean. Limnol. Oceanogr., 17: 885-900.

Codispoti, L.A. - 1973. Denitrification in the eastern tropical North Pacific. Ph. D. thesis, Univ. Washington.

Codispoti, L.A. - 1989. Phosphorus vs nitrogen limitation of new and export production. In: W. Berger, V. Smetacrek and G.
Wefer (eds.), Productivity of the ocean: Present and past, pp. 377-394. John Wiley and Sons, Chichester.

Codispoti, L.A. - 1995. Is the ocean losing fixed nitrogen? Nature, 376: 724

Codispoti. L.A., R.T. Barber and G.E. Friederich. - 1989. Do nitrogen transformations in the poleward undercurrent off Peru and Chile have a globally significant influence? In: J. Neshyba, C. Mooers and R. Barber (eds.), Poleward flows on eastern boundaries, pp. 281-310. Springer-Verlag, New York.

Codispoti, L.A. and J.P. Christensen. - 1985. Nitrification, denitrification and nitrous oxide cycling in the eastern tropical South Pacific Ocean. Mar. Chem., 16: 277-300.

Codispoti, L.A., J.W. Elkins, T. Yosinari, G.E. Friederich, C.M. Sakamoto and T.T. Packard. - 1992. On the nitrous oxide flux from productive regions that contain low oxygen waters. In: B N. Desai (ed.), Oceanography of the Indian Ocean, pp. 271284. Oxford and IBH, New Delhi.

Codispoti, L.A., G.E. Friederich, J.W. Murray and C.M. Sakamoto. - 1991a. Chemical variability in the Black-Sea - Implications of continuous vertical profiles that penetrated the oxic anoxic interface. Deep-Sea Res. Part 2, 38: S691-S710.

Codispoti, L.A., G.E. Friederich, T.T. Packard and R.T. Barber. 1988. Remotely driven thermocline oscillations and denitrification in the eastern South Pacific: The potential for high denitrification rates during weak coastal upwelling. T. Sci. T. Env., 75: 301-318.

Codispoti, L.A., G.E. Friederich, T.T. Packard, H.T. Glover, P.J. Kelly, R.W. Spinrad, R.T. Barber, J.W. Elkins, B.B. Ward, F. Lipschultz and N. Lostanau. - 1986. High nitrate levels off of the coast of Peru: A signal of instability in the marine denitrification rate. Science, 233: 1200-1202.

Codispoti, L.A., G.E. Friederich, C.M . Sakamoto and L.I. Gordon. 1991b. Nutrient cycling and primary production in the marine systems of the Arctic and Antarctic. J. Mar. Systems, 2: 359-384

Codispoti, L.A. and T.T. Packard. - 1980. Denitrification rates in the eastern tropical South Pacific. J. Mar. Res., 38: 453-477.

Codispoti, L.A. and F.A. Richards. - 1976. An analysis of the horizontal regime of denitrification in the eastern tropical North Pacific. Limnol. Oceanogr., 21: 379-388.

Cornell, S., A. Rendell and T. Jickells. - 1995. Atmospheric Inputs of Dissolved Organic Nitrogen to the Oceans. Nature, 376: 243-246.

Crutzen, P.J. and V. Ramanathan. - 2000. The ascent of atmospheric sciences. Science, 290: 299-304.

Dendooven, L. and J.M. Anderson. - 1994. Dynamics of reduction enzymes involved in the denitrification process in Pasture Soil. Soil Biol. Biochem., 26: 1501-1506.

Devol, A. - 1991. Direct measurements of nitrogen gas fluxes from continental shelf sediments. Nature, 349: 319-321.

Devol, A.H. - 1975. Biological oxidations in oxic and anoxic marine environments: Rates and processes. $\mathrm{Ph}$. D. thesis, Univ. Washington.

Devol, A.H., L.A. Codispoti and J.P. Christensen. - 1997. Summer and winter denitrification rates in western Arctic shelf sediments. Cont. Shelf Res., 17: 1029.

Dore, J.E., B.N. Popp, D.M. Karl and F.J. Sansone. - 1998. A large source of atmospheric nitrous oxide from subtropical North Pacific surface waters. Nature, 396: 63-66.

Duce, R.A., P.S. Liss, J.T. Merrill, E.L. Atlas, P. Buat-Menard, B.B. Hicks, J.M. Miller, J.M. Prospero, R. Arimoto, T.M Church, W. Ellis, J.N. Galloway, L. Hansen, T.D. Jickells, A.H. Knap, K.H. Reinhardt, B. Schneider, A. Soudine, J.J. Tokos, S. Tsunogai, R. Wollast and M. Zhou. - 1991. The atmospheric input of trace species to the world ocean. Glob. Biogeochem. Cycle., 5: 193-259.

Einsle, O., A. Messerschmidt, P. Stach, G.P. Bourenkov, H.D. Bartunik, R. Huber and P.M.H. Kroneck. - 1999. Structure of cytochrome $c$ nitrite reductase. Nature, 400: 476-480.

Emerson, S., C. Stump, D. Wilbur and P. Quay. - 1999. Accurate measurement of $\mathrm{O}_{2}, \mathrm{~N}_{2}$, and Ar gases in water and the solubility of $\mathrm{N}_{2}$. Mar. Chem., 64: 337-347.

Emery, K.O., W.L. Orr and S.C. Rittenberg. - 1955. Nutrient budgets in the ocean. In: Essays in the natural sciences in honor of captain Alan Hancock, pp. 299-310. University of Southern Carolina Press, Los Angeles.

Eriksson, E. - 1959. The circulation of some atmospheric constituents in the sea. In: B. Bolin (ed.), The atmosphere and the sea in motion, the Rossby memorial volume, pp. 147-157. 
Rockefeller Institute Press, New York.

Falkowski, P.G., R.J. Scholes, E. Boyle, J. Canadell, D. Canfield, J. Elser, N. Gruber, K. Hibbard, P. Hogberg, S. Linder, F.T Mackenzie, B. Moore, T. Pedersen, Y. Rosenthal, S. Seitzinger, V. Smetacek and W. Steffen. - 2000. The global carbon cycle: A test of our knowledge of earth as a system. Science, 290: 291-296.

Falkowski, P.G. - 1997. Evolution of the nitrogen cycle and its influence on the biological sequestration of $\mathrm{CO}_{2}$ in the ocean Nature, 387: 272-275.

Farias, L. - 1998. Potential role of bacterial mats in the nitrogen budget of marine sediments: the case of Thioploca sp. Mar. Ecol. Prog. Ser., 170: 291-292.

Farrenkopf, A.M., M.E. Dollhopf, S. NiChadhain, G.W. Luther and K.H. Nealson. - 1997a. Reduction of iodate in seawater during Arabian Sea shipboard incubations and in laboratory cultures of the marine bacterium Shewanella putrefaciens strain MR-4 Mar. Chem., 57: 347-354.

Farrenkopf, A.M., G.W. Luther, V.W. Truesdale and C.H. Van Der Weijden. - 1997b. Sub-surface iodide maxima: evidence for biologically catalyzed redox cycling in the Arabian Sea OMZ during the SW intermonsoon. Deep-Sea Res. II, 44:1391-1409.

Firestone, M.K. and J.M. Tiedje. - 1979. Temporal change in nitrous oxide and dinitrogen from denitrification following onset of anaerobiosis. Appl. Environ. Microbiol., 38: 673-679.

Flückiger, J., A. Dällenbach, T. Bunier, B. Stauffer, T.F. Stocker, D. Raynaud and J.-M. Barnola. - 1999. Variations in atmospheric $\mathrm{N}_{2} \mathrm{O}$ concentration during abrupt climate changes. Science, 285: 227-230.

Fossing, H., V.A. Gallardo, B.B. Jorgensen, M. Huttel, L.P Nielsen, H. Schulz, D.E. Canfield, S. Forster, R.N. Glud, J.K Gundersen, J. Kuver, N.B. Ramsing, A. Teske, B. Thamdrup and O. Ulloa. - 1995. Concentration and Transport of Nitrate by the Mat-Forming Sulfur Bacterium Thioploca. Nature, 374: 713-715.

Friederich, G.E., L.A. Codispoti and C.M. Sakamoto. - 1990. Bottle and pumpcast data from the 1988 Black Sea expedition. MBARI Tech. Rpt., 90-3.

Froelich, P.N., G.P. Klinkhammer, M.L. Bender, N.A. Luedtke, G.R. Heath, D. Cullen, P. Dauphin, D. Hammond, B. Hartman and V. Maynard. - 1979. Early oxidation of organic matter in pelagic sediments of the eastern equatorial Atlantic: Suboxic diagenesis. Geochem. Cosmochim. Acta, 43: 4043-4052.

Furman, J.A. and D.G. Capone. - 1991. Possible biogeochemical consequences of ocean fertilization. Limnol. Oceanogr., 36 1951-1959.

Galloway, JN., W.H. Schlesinger, H. Levy, A. Michaels and J.L. Schnoor. - 1995. Nitrogen-fixation - Anthropogenic enhancement-environmental response. Glob. Biogeochem. Cycle., 9: $235-252$.

Ganeshram, R.S., T.F. Pedersen, S.E. Calvert and J.W. Murray. 1995. Large changes in the oceanic nutrient inventories from glacial to interglacial periods. Nature, 376: 755-757.

Goering, J., F.A. Richards, L. Codispoti and R. Dugdale. - 1973 Nitrogen fixation and denitrification in the ocean: Biogeochemical budgets. In: E. Ingerson (ed.), Proc. International Symposium Hydrogeochemistry and Biogeochemistry, pp. 1227. Clarke, Ontario.

Goreau, T.J., W.A. Kaplan, S.C. Wofsy, M.B. McElroy, F.W. Valois and S.W. Watson. - 1980. Production of $\mathrm{NO}_{2}^{-}$and $\mathrm{N}_{2} \mathrm{O}$ by nitrifying bacteria at reduced concentrations of oxygen. Appl. Environ. Microbiol., 40: 526-532.

Gruber, N. and J.L. Sarmiento. - 1997. Global patterns of marine nitrogen fixation and denitrification. Glob. Biogeochem. Cycle., 11: 235-266.

Harvey, H.W. - 1960. Chemistry and fertility of sea-waters. Cambridge University Press, Cambridge.

Hellemans, G.E. - 1998. Global nitrogen overload problem grows critical. Science, 279: 988-989.

Hoering, T. and H.T. Ford. - 1960. The isotope effect in the fixation of nitrogen by Azobacter. J. Am. Chem. Soc., 82: 376.

Howarth, R.W., G. Billen, D. Swaney, A. Townsend, N. Jaworski, K. Lajtha, J.A. Downing, R. Elmgren, N. Caraco, T. Jordan, F. Berendse, J. Freney, V. Kudeyarov, P. Murdoch and Z. L. Zhu. - 1996. Regional nitrogen budgets and riverine N\&P fluxes for the drainages to the North Atlantic Ocean: Natural and human influences. Biogeochemistry, 35: 75-139.

Hutchinson, G.E. - 1957 and 1975. A treatise on limnology. John Wiley \& Sons, New York.
Jorgensen, B.B. and V.A. Gallardo. - 1999. Thioploca spp: filamentous sulfur bacteria with nitrate vacuoles. FEMS Microbiol. Ecol., 28: 301-313.

Karl, D.M., R. Letelier, D.V. Hebel, D.F. Bird and C.D. Winn. 1992. Trichodesmium blooms and new production in the North Pacific gyre. In: E. J. Carpenter (ed.), Marine and Pelagic Cyanobacteria: Trichnodesmium and other Diazotrophs, pp. 219-237. Klewer.

Karl, D.M., R. Letelier, D.V. Hebel, L. Tupas, J. Dore, J. Christian and C.D. Winn. - 1995. Ecosystem changes in the north Pacific Gyre attributed to the 1991-1992 El. Niño. Nature. 373: 230-234.

Kim, K.R. and H. Craig. $-1993 .{ }^{15} \mathrm{~N}$ and ${ }^{18} \mathrm{O}$ Characteristics of Nitrous-Oxide - A Global Perspective. Science, 262: 1855-1857.

Krest, J.M ., W.S. Moore, L.R. Gardner and J.T. Morris. - 2000. Marsh nutrient export supplied by groundwater discharge: Evidence from measurements. Glob. Biogeochem. Cycle., 14: 167-176.

Law, C.S. and N.J.P. Owens. - 1990. Significant flux of atmospheric nitrous oxide from the northwest Indian Ocean. Nature, 346: 826-828.

Lenton, T.M. and A.J. Watson. - 2000. Redfield revisited 1. Regulation of nitrate, phosphate, and oxygen in the ocean. Glob. Biogeochem. Cycle., 14: 225-248.

Leuenberger, M. and U. Siegenthaler. - 1992. Ice-age atmospheric concentration on nitrous oxide from an Antarctic ice core. Nature, 360: 449-451.

Levin, L.A., J. Gage, P. Lamont, L. Cammidge, C. Martin, A. Patience, J. Crooks. - 1997. Infaunal community structure in a low-oxygen, organic rich habitat on the Oman continental slope, NW Arabian Sea. In: L. E. Hawkins, S. Hutchinson (eds.), The responses of marine organisms to their environments, pp. 223-230. Proceedings of the $30^{\text {th }}$ Marine Biology Symposium. Univ. Southampton.

Lewis, B.L. and G.W. Luther. - 2000. Processes controlling the distribution and cycling of manganese in the oxygen minimum zone of the Arabian Sea. Deep-Sea Res. Part II, 47: 1541-1561.

Lewis, G.N. and M. Randall. - 1923. Thermodynamics and the free energy of chemical substances. McGraw Hill, New York.

Lipschultz, F. and N.J.P. Owens. - 1996. An assessment of nitrogen fixation as a source of nitrogen to the North Atlantic Ocean. Biogeochemistry, 35: 261-274.

Liu, K.K. - 1979. Geochemistry of inorganic nitrogen compounds in two marine environments: The Santa Barbara Basin and the ocean off of Peru. Ph. D. thesis, University of California.

Lloyd, D., L. Boddy and J.P. Davies. - 1987. Persistence of bacterial denitrification capacity under aerobic conditions: the rule rather than the exception. FEMS Microb. Ecolo., 45: 185-190.

Luther, G.W., B. Sundby, B.L. Lewis, P.J. Brendel and N. Silverberg. - 1997. Interactions of manganese with the nitrogen cycle: Alternative pathways to dinitrogen. Geochim. Cosmochim. Acta, 61: 4043-4052.

Magnuson, J.J. - 1990. Long-term ecological research and the invisible present. Bioscience, 40: 495-501.

Malakoff, D. - 1998. Death by suffocation in the Gulf of Mexico. Science, 281: 190-192

Manne, A.S. and R.G. Richels. - 2001. An alternative approach to establishing trade-offs among greenhouse gases. Nature, 410: 675-677.

Mantoura, R.F.C., C.S. Law, N.J.P. Owens, P.H. Burkill, E.M.S. Woodward, R.J.M. Howland and C.A. Llewellyn. - 1993. Nitrogen biogeochemical cycling in the northwestern IndianOcean. Deep-Sea Res. Part II, 40: 651-671.

Mantua, N.J., S.R. Hare, Y. Zhang, J.M. Wallace and R.C. Francis. 1997. A Pacific interdecadal climate oscillation with impacts on salmon production. Bull. Amer. Meteorol. Soc., 78: 1069-1079.

Margalef, R. - 1974. Ecologia. Edicions Omega, Barcelona.

McElroy, M.B. - 1983. Marine biological controls on the atmospheric $\mathrm{CO}_{2}$ climate. Nature, 302: 328-329.

Middelburg, J.J., K. Soetaert, P.M.J. Herman and C.H.R. Heip. 1996. Denitrification in marine sediments: A model study. Glob. Biogeochem. Cycle., 10: 661-673.

Minagawa, M. and E. Wada. - 1986. Nitrogen isotope ratios of red tide organisms in the eastern China Sea: A characterization of biological nitrogen fixation. Mar. Chem. 19: 245.

Moore, W.S. - 1996. Large groundwater inputs to coastal waters revealed by ${ }^{226} \mathrm{Ra}$ enrichments. Nature, 380: 612-614.

Morrison, J.M., L.A. Codispoti, S. Gaurin, B. Jones, V. Manghnani and Z. Zheng. - 1998. Seasonal variation of hydrographic and 
nutrient fields during the US JGOFS Arabian Sea process study. Deep-Sea Res. Part II, 45: 2053-2101.

Morrison, J.M., L.A. Codispoti, S.L. Smith, K. Wishner, C. Flagg, W.D. Gardner, S. Gaurin, S.W.A. Naqvi, V. Manghnani, L. Prosperie and J.S. Gundersen. - 1999. The oxygen minimum zone in the Arabian Sea during 1995. Deep-Sea Res. Part II, 46: 1903-1931.

Murray, J.W., L.A. Codispoti and G.E. Frederich. - 1995a. Oxidation-reduction environments - The suboxic zone in the Black Sea. In: C. P. Huang, C. R. O’Melia and J. J. Morgan (eds.), Aquatic Chemistry, pp. 157-176. American Chemical Society, Washington DC.

Murray, J.W., H.W. Jannasch, R.F. Honjo, R.F. Anderson, W.S. Reeburgh, Z. Top, G.E. Frederich, L.A. Codispoti and E. Izdar. - 1989. Unexpected changes in the oxic/anoxic interface in the Black Sea. Nature, 338: 411-413.

Naqvi. S.W.A. - 1987. Some aspects of the oxygen deficient conditions and denitrification in the Arabian Sea. J. Mar. Res., 45: 1049-1072.

Naqvi, S.W.A., H.P. Hansen and T.W. Kureishy. - 1986. Nutrient uptake and regeneration ratios in the Red Sea with reference to the nutrient budgets. Oceanolog. Acta, 9: 271-276.

Naqvi, S.W.A. - 1990. Denitrification processes in the Arabian Sea. In: D. Lal (ed.), Biogeochemistry of the Arabian Sea, pp. 181203. Indian Academy of Sciences, New Delhi.

Naqvi, S.W.A. and D.A. Jayakumar. - 2000a. Ocean biogeochemistry and atmospheric composition: Significance of the Arabian Sea. Curr. Sci., 78: 289-299.

Naqvi, S.W.A., D.A. Jayakumar, P.V. Narvekar, H. Naik, V. Sarma, W. D'Souza, S. Joseph and M.D. George. - 2000a. Increased marine production of $\mathrm{N}_{2} \mathrm{O}$ due to intensifying anoxia on the Indian continental shelf. Nature, 408: 346-349.

Naqvi, S.W.A, A. Jayakumar, T. Yoshinari, A.H. Devol, P.V. Narvekar, H. Naik and L.A. Codispoti. - 2000b. Seasonal bottom-water anoxia over the western continental shelf of India: Effect on nitrous oxide cycling. EOS Trans. AGU Fall Meet. Supp.,l (Abstract) 81 (48).

Naqvi, S.W.A. and R.J. Noronha. - 1991. Nitrous oxide in the Arabian Sea. Deep-Sea Res., 38: 871-890.

Naqvi, S.W.A. and R. Sen Gupta. - 1985. 'NO', a useful tool for the estimation of nitrate deficits in the Arabian Sea. Deep-Sea Res., 35: 665-674.

Naqvi, S.W.A. and M.S. Shailaja. - 1993. Activity of the respiratory electron-transport system and respiration rates within the oxygen minimum layer of the Arabian Sea. Deep-Sea Res. Part II, 40: 687-695.

Naqvi, S.W.A., T. Yoshinari, D.A. Jayakumar, M.A.P.V. Narvekar, A.H. Devol, J.A. Brandes and L.A. Codispoti. - 1998. Budgetary and biogeochemical implications of $\mathrm{N}_{2} \mathrm{O}$ isotope signatures in the Arabian Sea. Nature, 394: 462-464.

Nevison, C. and E. Holland. - 1997. A reexamination of the impact of anthropogenically fixed nitrogen on atmospheric $\mathrm{N}_{2} \mathrm{O}$ and the stratospheric $\mathrm{O}_{3}$ layer. J. Geophys. Res.-Atmos., 102: 25519-25536.

Nevison, C.D., R.F. Weiss and D.J. Erickson. - 1995. Global oceanic emissions of nitrous oxide. J. Geophys. Res.-Oceans, 100: 15809-15820.

Nixon, S.W., J.W. Ammerman, L.P. Atkinson, V.M. Berounsky, G. Billen, W.C. Boicourt, W.R. Boynton, T.M. Church, D.M. Ditoro, R. Elmgren, J.H. Garber, A.E. Giblin, R.A. Jahnke, N.J.P. Owens, M.E.Q. Pilson and S.P. Seitzinger. - 1996. The fate of nitrogen and phosphorus at the land sea margin of the North Atlantic Ocean. Biogeochemistry, 35: 141-180.

Ostrom, N.E., M.E. Russ, B. Popp, R.T.M. and D.M. Karl. - 2000. Mechanisms of nitrous oxide production in the subtropical North Pacific based on determinations of the isotopic abundances of nitrous oxide and di-oxygen. Chemosphere-Global Change Sci. 2, 2: 281-290.

Otte, S., J.G. Kuenen, L.P. Nielsen, H.W. Paerl, J. Zopfi, H.N. Schulz, A. Teske, B. Strotmann, V.A. Gallardo and B.B. Jorgensen. 1999. Nitrogen, carbon, and sulfur metabolism in natural Thioploca samples. Appl. Environ. Microbiol., 65: 3148-3157.

Oudet, C., C. Andrie and Y. Montel. - 1990. Nitrous oxide production in the tropical Atlantic Ocean. Deep-Sea Res., 37: 183-202.

Paerl, H.W. - 1990. Physiological ecology and regulation of $\mathrm{N}_{2}$ fixation in natural waters. Adv. Microb. Ecol., 8: 305-344.

Paerl, H.W. - 1997. Coastal eutrophication and harmful algal blooms: Importance of atmospheric deposition and groundwa- ter as "new" nitrogen and other nutrient sources. Limnol. Oceanogr., 42: 1154-1165.

Paerl, H.W., J.D. Bales, L.W. Ausley, C.P. Buzzelli, L.B. Crowder, L.A. Eby, J.M. Fear, B.L. Peierls, T. L. Richardson and J.S. Ramus. - 2001. Ecosystem impacts of 3 sequential hurricanes (Dennis, Floyd and Irene) on the US's largest lagoonal estuary, Pamlico Sound, NC. Proc. Natl. Acad. Sci., 98(10): 5655-5660.

Paerl, H.W. J.D. Bales, L.W. Ausley, C.P. Buzzelli, L.B. Crowder, L.A. Eby, M. Go, B.L. Peierls, T.L. Richardson and J.S Ramus. - 2000. Hurricanes' hydrological, ecological effects linger in major US estuary. EOS, 81: 457-462.

Paerl, H.W., J.L. Pinckney and S.A. Kucera. - 1995. Clarification of the structural and functional roles of heterocysts and anoxic microzones in the control of pelagic nitrogen-fixation. Limnol. Oceanogr., 40: 634-638.

Paerl, H.W. and L.E. Prufert. - 1987. Oxygen-poor microzones as potential sites of microbial $\mathrm{N}_{2}$ fixation in nitrogen depleted aerobic marine waters. Appl. Environ. Micobiol., 53: 1078-1087.

Paerl, H.W. and J.P. Zehr. - 2000. Marine nitrogen fixation. In: D L. Kirchman (ed.), Microbial ecology of the oceans, pp. 387 426. Wiley-Liss, New York.

Pierotti, D. and R. A. Rasmussen. - 1980. Nitrous oxide measurements in the eastern tropical Pacific Ocean. Tellus, 32: 56-72.

Piper, D.Z. and L.A. Codispoti. - 1975. Marine phosphorite deposits and the nitrogen cycle. Science, 188: 15-18.

Poth, M. and D.D. Focht. $-1985 .{ }^{15} \mathrm{~N}$ kinetic analysis of $\mathrm{N}_{2} \mathrm{O}$ production by Nitrosomonas europaea: An examination of nitrifier denitrification. Appl. Environ. Microbiol., 49: 1134-1141.

Rabalais, N.N., R.E. Turner, D. Justic, Q. Dortch, W.J. Wiseman and B.K. Sen Gupta. - 2000. Gulf of Mexico biological system responses to nutrient changes in the Mississippi River. In: J.E. Hobbie (ed.), Estuarine science a synthetic approach to research and practice, pp. 241-268. Island Press, Washington D.C.

Raven, J.A. - 1988. The iron and molybdenum use efficiencies of plant growth with different energy, carbon and nitrogen sources. New Phytol. 109: 279-287.

Redfield, A., B.H. Ketchum and F.A. Richards. - 1963. The influence of organisms on the composition of seawater. In: M. N. Hill (ed.), The Sea, pp. 26-77. Academic Press, New York.

Reid, J.L. - 1973. Transpacific hydrographic sections at Lats. $43^{\circ} \mathrm{S}$ and $28^{\circ} \mathrm{S}$ the Scorpio Expedition - Upper water; and a note on southward flow at mid-depth. Deep-Sea Res., 20: 39-49.

Richards, F.A. - 1965. Anoxic basins and fjords. In: J. P. Ripley and G. Skirrow (eds.), Chemical oceanography, pp. 611-645. Academic Press, London and New York.

Richards, F.A. - 1975. The Cariaco Basin (Trench). In: H. Barns (ed.), Oceanography and marine biology: An annual review, pp. 11-67. George Allen and Unwin Ltd., London.

Richards, F.A. and B.B. Benson. - 1960. Nitrogen/argon and nitrogen isotope ratios in two anaerobic environments, the Cariaco Trench in the Caribbean Sea and Dramsford, Norway. DeepSea Res., 7: 254-264.

Ritchie, G.A.F. and D.J.D. Nicholas. - 1972. Identification of the sources of nitrous oxide produced by oxidative and reductive processes in Nitrosomonas europaea. Biochem. J., 126: 11811191.

Rönner, U. - 1983. Biological nitrogen transformations in marine ecosystems with emphasis on denitrification. Ph. D. thesis, Univ. Goteborg.

Saager, P.M., H.J.W. De Baar and P.H. Burkill. - 1989. Manganese and iron in Indian Ocean waters. Geochem. Cosm. Acta, 53: 2259-2267.

Sañudo-Wilhelmy, S.A., A.B. Kustka, C.J. Gobler, D.A. Hutchins, M. Yang, K. Lwiza, J. Burns, D.G. Capone, J.A. Raven and E.J. Carpenter - 2001. Phosphorus limitation of nitrogen fixation by Trichodesmium in the central Atlantic Ocean. Nature, 411: 66-69.

Schulz, H.N., T. Brinkhoff, T.G. Ferdelman, M.H. Marine, A. Teske and B.B. Jorgensen. - 1999. Dense populations of a giant sulfur bacterium in Namibian shelf sediments. Science, 284: 493-495.

SCOR. - 1996. JGOFS Report No 19:Protocols for the Joint Global Ocean Flux Study (JGOFS) Core measurements. Scientific committee on oceanographic research, international council of scientific unions, Bergen, pp.170.

Scranton, M.I., F.L. Sayles, M.P. Bacon and P.G. Brewer. - 1987. Temporal changes in the hydrography and chemistry of the 
Cariaco Trench. Deep-Sea Res., 34: 945-963.

Seitzinger, S.P., L.P. Nielsen, J. Caffrey and P.B. Christensen. 1993. Denitrification measurements in aquatic sediments - A comparison of three methods. Biogeochemistry, 23: 147-167.

Shaffer, G. and U. Rönner. - 1984. Denitrification in the Baltic proper deep water. Deep-Sea Res., 31: 197-200.

Sigman, D.M., M.A. Altabet, R. Francois, D.C. McCorkle and J.F Gaillard. - 1999. The isotopic composition of diatom-bound nitrogen in Southern Ocean sediments. Paleoceanography, 14 $118-134$

Smil, V. - 1997. Global population and the nitrogen cycle. Sci. Am., 277 (1):76-81.

Smith, S.V., J.T. Hollibaugh, S.J. Dollar and S. Vink. - 1989 Tomales Bay, California: A case for carbon-controlled nitrogen cycling. Limnol. Oceanogr., 31: 37-52.

Söderlund, R. and B.H. Svensson. - 1976. The global nitrogen cycle. In: B.H. Svensson and R. Söderlund (eds.), Nitrogen, phosphorus and sulphur - Global cycles, SCOPE Report 7, pp.23-73. Ecological Bulletins No. 22/Royal Swedish Academy of Sciences, Orsundsbro.

Spalding, R.F. and M.E. Exner. - 1993. Occurrence of nitrate in groundwater-A Review. J. Environ. Oual., 22: 392-402.

Spencer, D.W. and P.G. Brewer. - 1971. Vertical advection diffusion and redox potentials as controls on the distribution of manganese and other trace metals dissolved in the waters of the Black Sea. J. Geophy. Res., 76: 5877-5899.

Stott, L.D., W. Berelson, R. Douglas and D. Gorsline. - 2000 Increased dissolved oxygen in Pacific intermediate waters due to lower rates of carbon oxidation in sediments. Nature, 407 : $367-370$.

Stouthamer, A.H. - 1988. Dissimilatory reduction of oxidized nitrogen compounds. In: A. J. B. Zehnder (ed.), Biology of Anaerobic Microorganisms. pp. 245-303. Wiley-Liss, New York.

Strous, M., J.A. Fuerst, E.H.M. Kramer, S. Logemann, G. Muyzer, K.T. van de Pas-Schoonen, R. Webb, J.G. Kuenen and M.S.M. Jetten. - 1999. Missing lithotroph identified as new planctomycete. Nature, 400: 446-449.

Suntharalingam, P., J.L. Sarmiento and J.R. Toggweiler. - 2000. Global significance of nitrous-oxide production and transport from oceanic low-oxygen zones: A modeling study. Glob. Biogeochem. Cycle., 14: 1353-1370.

Thompson, D.W.J. and J.M. Wallace. - 1998. The Arctic Oscillation signature in the wintertime geopotential height and temperature fields. Geophys. Res. Lett., 25: 1297-1300

Tiedje, J.M. - 1988. Ecology of denitrification and dissimilatory nitrate reduction to ammonium. In: J. B. Zehnder (ed.), Biology of Anaerobic Microorganisms, pp. 179-244. Wiley-Liss, New York.
Tsunogai, S. - 1971. Ammonia in the ocean atmosphere and the cycle of nitrogen compounds through the atmosphere and the hydrosphere. The Geochem. Soc. Japan, Geochem. J., 5: 57-67.

Tsunogai, S. and K. Ikeuchi. - 1968. Ammonia in the atmosphere. The Geochem Soc. of Japan, Geochem. J., 2: 157-166.

Tyrrell, T. - 1999. The relative influences of nitrogen and phosphorus on oceanic primary production. Nature, 400: 525-531.

Uhulenhopp, A.G., A.H. Devol, S.W.A. Naqvi, A.A. Jayakumar, T. Yoshinari and L.A. Codispoti. - (in preparation). Arabian Sea denitrification rates from ${ }^{15} \mathrm{~N}$ incubations, excess $\mathrm{N}_{2}$ values, and nitrate deficits suggest that prevailing estimates are low.

Van Mooy, B.A.S., R.G. Keil and A. Devol. - (in press). Enhanced flux of particulate organic matter in oxygen deficient waters: Impact of suboxia on early degradation. Geochem. Cosm. Acta.

Vitousek, P.M., J.D. Aber, R.W. Howarth, G.E. Likens, P.A. Matson, D.W. Schindler, W.H. Schlesinger and D.G. Tilman. 1997a. Human alteration of the global nitrogen cycle: Sources and consequences. Ecol. Appl., 7: 737-750.

Vitousek, P.M., H.A. Mooney, J. Lubchenco and J.M. Melillo. 1997b. Human domination of the Earth's ecosystems. Science. 277: 494-499.

Ward, B.B. and O.C. Zafiriou. - 1988. Nitrification and nitric oxide in the oxygen minimum of the eastern tropical North Pacific. Deep-Sea Res., 35: 1127-1142.

Watling, L. and E. A. Norse. - 1998. Disturbance of the seabed by mobile fishing gear: A comparison to forest clearcutting. Conserv. Biol., 12: 1180-1197.

Witter, A.E., B.L. Lewis and G. W. Luther III. - 2000. Iron speciation in the Arabian Sea. Deep-Sea Res. II., 47: 1517-1539.

Wolgast, D.M., A.F. Carlucci and J.E. Bauer. - 1998. Nitrate respiration associated with detrital aggregates in aerobic bottom waters of the abyssal NE Pacific. Deep-Sea Res. Part II, 45: 881-892.

Yamazaki, T., N. Yoshida, E. Wada and S. Matsuo. - 1987. NO Reduction by Azotobacter vinelandii with emphasis on kinetic nitrogen isotope effects. Plant Cell Physiol., 28: 263-271.

Yoshinari, T., M.A. Altabet, S.W.A. Naqvi, L. Codispoti, A. Jayakumar, M. Kuhland and A. Devol. - 1997. Nitrogen and oxygen isotopic composition of $\mathrm{N}_{2} \mathrm{O}$ from suboxic waters of the eastern tropical North Pacific and the Arabian Sea - Measurement by continuous-flow isotope-ratio monitoring. Mar. Chem., 56: 253-264.

Yoshinari, T. and I. Koike. - 1994. The use of stable isotopes for the studies of gaseous nitrogen species in the marine environments. In: J.H. Lawton and G.E. Likens (eds.), Stable isotopes in ecology and environmental science, pp. 114-137. Blackwell Scientific, London. 